\title{
Targeting CD22 with the monoclonal antibody epratuzumab modulates human B-cell maturation and cytokine production in response to Toll-like receptor 7 (TLR7) and $\mathrm{B}$-cell receptor $(\mathrm{BCR})$ signaling
}

\author{
Natalia V. Giltiay ${ }^{1,2^{*}}$, Geraldine L. Shu², Anthony Shock ${ }^{3}$ and Edward A. Clark ${ }^{1,2}$
}

\begin{abstract}
Background: Abnormal B-cell activation is implicated in the pathogenesis of autoimmune diseases, including systemic lupus erythematosus (SLE). The B-cell surface molecule CD22, which regulates activation through the B-cell receptor $(B C R)$, is a potential target for inhibiting pathogenic $B$ cells; however, the regulatory functions of CD22 remain poorly understood. In this study, we determined how targeting of CD22 with epratuzumab (Emab), a humanized anti-CD22 lgG1 monoclonal antibody, affects the activation of human B-cell subsets in response to Toll-like receptor 7 (TLR7) and BCR engagement.

Methods: B-cell subsets were isolated from human tonsils and stimulated with $\mathrm{F}\left(\mathrm{ab} \mathrm{b}^{\prime}\right)_{2}$ anti-human $\operatorname{lgM}$ and/or the TLR7 agonist R848 in the presence of Emab or a human IgG1 isotype control. Changes in mRNA levels of genes associated with B-cell activation and differentiation were analyzed by quantitative PCR. Cytokine production was measured by ELISA. Cell proliferation, survival, and differentiation were assessed by flow cytometry.

Results: Pretreatment of phenotypically naïve $\mathrm{CD} 19^{+} \mathrm{CD} 10^{-} \mathrm{CD} 27^{-}$cells with Emab led to a significant increase in IL-10 expression, and in some but not all patient samples to a reduction of IL-6 production in response to TLR7 stimulation alone or in combination with anti-lgM. Emab selectively inhibited the expression of PRDM1, the gene encoding B-lymphocyte-induced maturation protein 1 (Blimp-1) in activated $\mathrm{CD} 10^{-} \mathrm{CD} 27^{-}$B cells. $\mathrm{CD} 10^{-} \mathrm{CD} 27^{-} \mathrm{lgD}{ }^{-}$ cells were highly responsive to stimulation through TLR7 as evidenced by the appearance of blasting CD27 ${ }^{\text {hi }} \mathrm{CD} 38^{\text {hi }}$ cells. Emab significantly inhibited the activation and differentiation of $\mathrm{CD}^{-} \mathrm{C}^{-} \mathrm{CD} 27^{-} \mathrm{IgD}{ }^{-} \mathrm{B}$ cells into plasma cells.

Conclusions: Emab can both regulate cytokine expression and block Blimp1-dependent B-cell differentiation, although the effects of Emab may depend on the stage of B-cell development or activation. In addition, Emab inhibits the activation of $\mathrm{CD}^{2} 7^{-} \mathrm{IgD}{ }^{-}$tonsillar cells, which correspond to so-called double-negative memory B cells, known to be increased in SLE patients with more active disease. These data may be relevant to the therapeutic effect of Emab in vivo via modulation of the production of pro-inflammatory and anti-inflammatory cytokines by B cells. Because Blimp-1 is required by B cells to mature into antibody-producing cells, inhibition of Blimp1 may reduce autoantibody production.
\end{abstract}

Keywords: Antibodies, B cells, B-cell targeted therapy, CD22, IL-6, IL-10, Epratuzumab, Systemic lupus erythematosus, TLR7

\footnotetext{
* Correspondence: giltiayn@uw.edu

'Division of Rheumatology, Department of Medicine, University of

Washington, Seattle, WA 98109, USA

2Department of Immunology, University of Washington, Seattle, WA 98109,

USA

Full list of author information is available at the end of the article
} 


\section{Background}

B cells are central mediators of humoral immunity and play a key role in the protection against pathogens. However, aberrant B-cell activation is a common feature of many autoimmune diseases including systemic lupus erythematosus (SLE), primary Sjögren's syndrome (pSS), and rheumatoid arthritis (RA). B cells may contribute to the pathogenesis of autoimmune diseases through several mechanisms, including both antibody (Ab)dependent functions (e.g., secretion of autoantibodies (auto-Abs)) and Ab-independent functions, such as antigen (Ag) presentation to $\mathrm{T}$ cells and production of pro-inflammatory cytokines $[1,2]$.

SLE is a complex, systemic autoimmune disease with highly diverse clinical manifestations [3]. The hallmarks of the disease are polyclonal B-cell activation, production of auto-Abs against nuclear-containing Ags, and organ damage due to immune complex deposition. Abnormalities in various B-cell compartments have been described in SLE patients, including expansion of newly formed (transitional) cells, as well as an expansion of Ag-experienced $\mathrm{CD}^{2} 7^{+} / \mathrm{IgD}^{-}$switched memory B cells and $\mathrm{CD}^{2} 7^{-} \mathrm{IgD}{ }^{-}$double-negative (DN) memory B cells $[2,4-6]$. Previous studies have shown that the frequency of circulating $\mathrm{CD} 20^{-} \mathrm{CD} 27^{++}$plasma cells correlates with SLE disease activity and auto-Ab titers [7]; however, the cellular origins of Ab-producing cells in SLE as well as the signals that drive their activation are not well defined. Alterations in the balance of signals downstream of the B-cell receptor (BCR) and pro-survival signals may contribute to the loss of immune tolerance and to the survival and activation of autoreactive B cells $[8,9]$. Dysregulation of BCR signaling, including increased phosphorylation of Syk and decreased phosphorylation of phosphatase activities, has also been described in SLE patients $[10,11]$.

B-cell activation via innate immune receptors, including endosomal Toll-like receptors (TLRs) expressed in B cells, may play a key role in driving autoreactive B cells in SLE [9, 12-15]. In mice, RNA-associated autoantigens activate autoreactive B cells by engaging BCRs and TLR7, an endosomal TLR specialized in the recognition of viral ssRNA, and induce the production of auto-Abs [12, 16]. Data from murine lupus models further support a role for TLR7 in SLE pathogenesis. Extra copies of the Tlr7 gene drive lupus-like disease [17-19]; whereas lupus-prone Tlr7-deficient mice develop attenuated disease symptoms $[20,21]$. Importantly, B-cell-intrinsic TLR7 signals can drive cell proliferation and differentiation and amplify auto-Ab production to further exacerbate SLE disease in mice [22]. In humans, genetic studies have demonstrated a correlation between genetic variations associated with dysregulation of TLR7 expression and SLE susceptibility [23-25].
Despite significant evidence implicating TLR7 in SLE, the effects of TLR7 on human B cells have not been explored fully. Little is known about the signals that can regulate TLR7-mediated activation of human B cells. IFN$\alpha$ can promote human B-cell responses to TLR7 ligation, most likely through its ability to upregulate TLR7 receptor levels [26]. In-vitro stimulation of $\mathrm{CD} 19^{+} \mathrm{CD} 27^{-}$blood $\mathrm{B}$ cells with a synthetic TLR7 ligand induces IgM and IgG production as well as secretion of IL-6 and IL-10 [27]. TLR7 activation also expands $\operatorname{IgM}^{+} \mathrm{CD} 27^{+}$memory B cells and $\mathrm{CD} 27^{\text {hi }} \mathrm{B}$ cells, and a combination of TLR7 plus IFN$\alpha$ promotes the production of auto-Abs [28]. Thus, TLR7mediated activation of human $B$ cells, as with mouse $B$ cells, can induce the production of auto-Abs.

While signals from BCR and TLR7 can synergize and promote inappropriate activation of autoreactive B cells, the engagement of other surface receptors, such as CD19 and CD22, have been proposed to inhibit their activation [29, 30]. The CD22 Siglec receptor family member is expressed predominantly on B cells and binds via its extracellular ligand-binding domain to $\alpha 2-6$ linked sialic acids on glycoproteins expressed on the same cell (cis interactions) or on opposing cells and/or soluble proteins (trans interactions) [31, 32]. CD22 acts as an adhesion receptor and functions to regulate B-cell migration [33-35]. Crosslinking of CD22 and the BCR triggers phosphorylation of the CD22 cytoplasmic tail, leading to the activation of a number of signaling molecules, known to either inhibit the BCR signaling or to promote the activation of JNK/SAPK and mitogen activated protein kinase ERK2 [30, 36, 37]. In addition to its function in regulating $\mathrm{BCR}$ signaling, $\mathrm{CD} 22$ has been implicated in the regulation of TLR-mediated signaling in B cells [38]. CD22 $2^{-1-} \mathrm{B}$ cells have hyperactive responses to TLR stimulation compared to wild-type (WT) B cells [38, 39]. Furthermore, studies have shown that LPS-induced activation of nuclear factor- $\mathrm{kB}$ (NF$\kappa B)$ downstream of TLR4 is inhibited by the expression of CD22 [38].

The expression of both CD22 and its ligands vary according to the $\mathrm{B}$-cell maturation/activation state. In the periphery, $\mathrm{CD} 22$ is expressed at maximum density on human $\mathrm{CD}^{-} 7^{-}$naïve and transitional $\mathrm{B}$ cells, while it is downregulated by plasma cells $[40,41]$. CD22 availability on the cell surface is also dependent on masking or unmasking of CD22 by endogenous (cis) ligand interactions [42]. The expression of CD22 ligands on human B cells is less well explored, but recent studies have shown that, due to changes in glycosylation, germinal center (GC) B cells lose the expression of high-affinity CD22 ligands, leading to CD22 "unmasking" [43].

The development of monoclonal Abs designed to target human CD22 [44] as well recent advances in human B-cell phenotyping [45] provide new opportunities to 
explore the effects of CD22 engagement on different subsets of human B-cell subsets. Epratuzumab (Emab), a humanized anti-human CD22 IgG1 Ab, has previously shown promising clinical activity both as a single agent and in combination with rituximab in patients with nonHodgkin's lymphoma (NHL) [46]. Unlike rituximab, which depletes circulating B cells, Emab does not induce complement-dependent cytotoxicity or Ab-dependent cellular cytotoxicity [47]. CD22 ligation by Emab, however, provokes rapid internalization and phosphorylation of CD22, inhibits the phosphorylation of Syk and PLCy2, and reduces intracellular $\mathrm{Ca}^{2+}$ mobilization after $\mathrm{BCR}$ stimulation in vitro $[44,48,49]$. Given the role of CD22 in modulating both BCR and TLR signaling, targeting CD22 with Emab has also been explored as a therapy for autoimmune diseases, including SLE and pSS [50, 51]. Phase I and IIb clinical trials have demonstrated clinically relevant, sustained improvements in patients with moderate-to-severe SLE and a good safety profile of Emab [52, 53]. Emab treatment was found to induce a partial reduction of circulating B cells in SLE patients affecting primarily $\mathrm{CD} 27^{-}$cells [54], a phenomenon that later led to an exploration of the in-vitro effects of Emab on the expression of the adhesion molecules CD62L, $\beta 7$ integrin, and $\beta 1$ integrin and on B-cell migration toward CXCL12 [41]. CD22 binding by Emab also induces a reduction of CD19, CD21, and CD79b expression through a process known as trogocytosis (i.e., Fc-mediated receptor "shaving" to other effector cells). In line with these findings, a decrease in CD19 expression was observed in SLE patients treated with Emab [55]. Recent studies have also investigated the effects of Emab on cytokine production. Emab inhibited IL-6 and tumor necrosis factor alpha (TNF- $\alpha$ ) production of blood B cells isolated from healthy donors and SLE patients in response to BCR crosslinking alone or in combination with TLR9 ligand CpG [56]. Overall, the available data led to the hypothesis that the primary mode of action of Emab is to enhance the normal inhibitory role of CD22 on B-cell activation [57].

Given the importance of TLR7 signaling in activating autoreactive B cells in SLE, we investigated whether CD22 crosslinking by Emab might affect B-cell activation in response to BCR and/or TLR7 stimulation. We further aimed to identify which subpopulation of human $B$ cells might be affected to the greatest extent by Emab in the context of BCR/TLR7 stimulation. Using human tonsillar $\mathrm{CD} 10^{-} \mathrm{CD} 27^{-} \mathrm{B}$ cells, we found that Emab modulates cytokine production by inhibiting IL-6, while at the same time enhancing IL-10 production. Emab dramatically and selectively inhibited levels of PRDM1, the gene encoding Blimp-1 in $\mathrm{CD} 10^{-} \mathrm{CD} 27^{-}$tonsillar $\mathrm{B}$ cells, activated by either TLR7 signaling alone or in combination with BCR stimulation. Tonsillar B-cell subsets responded differently to BCR/TLR7 stimulation; among them $\mathrm{CD} 10^{-} \mathrm{CD} 27^{-} \mathrm{IgD}{ }^{-}$cells, which correspond to DN memory $\mathrm{B}$ cells found in the periphery, were most responsive to TLR7 stimulation, as evidenced by the appearance of $\mathrm{CD} 27^{\mathrm{hi}} \mathrm{CD} 38^{\text {hi }} \mathrm{Blimp} 1^{+}$plasmablasts. In particular, Emab inhibited the in-vitro differentiation of $\mathrm{CD} 10^{-} \mathrm{CD} 27^{-} \mathrm{IgD}{ }^{-}$and $\mathrm{CD} 10^{+} \mathrm{CD} 27^{-/+} \mathrm{B}$ cells and reduced the survival of $\mathrm{CD} 10^{+} \mathrm{CD} 27^{-/+} \mathrm{B}$ cells but not other B-cell subsets. Thus, Emab can both enhance and inhibit TLR7-driven B-cell responses: depending on the Bcell developmental/maturation state, CD22 crosslinking by Emab affects B-cell survival, activation, and differentiation differently, which may have important implications for the clinical use of Emab and monitoring of CD22based therapies.

\section{Methods}

\section{Cell preparation and purification}

Post-surgical tonsillar tissue samples were obtained from Valley Medical Day Surgery Center (Renton, WA, USA) in accordance with an IRB approved protocol. Cell suspensions were prepared by gently teasing tissues in R10 medium (RPMI 1640 containing 10\% FBS (ThermoFisher Scientific), $100 \mathrm{U} / \mathrm{ml}$ penicillin, $100 \mathrm{mg} / \mathrm{ml}$ streptomycin, $2 \mathrm{mM}$ L-glutamine, $1 \mathrm{mM}$ sodium pyruvate, and $10 \mathrm{mM}$ Hepes) with forceps and scissors, and then separating cells over Ficoll-Hypaque (GE Healthcare Life Sciences). Tonsillar B cells were enriched by depleting $\mathrm{CD} 2^{+} \mathrm{T}$ and NK cells using sheep erythrocytes, a technique that relies on the formation of immunorosettes (i.e., rosetting) [58], and then separated again over Ficoll-Hypaque. Samples after rosetting were typically $\geq 90 \%$ pure CD $20^{+}$B cells. In some experiments, cells were further enriched for CD27 $\mathrm{CD} 10^{-} \mathrm{B}$ cells using biotinylated monoclonal Abs (mAbs) against CD3 (G19-4), CD5 (10.2), CD10 (CB-CALLA), and CD27 (O323) (eBioscience) with the StemCell Technologies Human Biotin Selection Kit for negative selection. In other experiments, post-rosetted cells were stained with fluorescently labeled mAbs (anti-CD3, CD27, CD10, and IgD antibodies) and then sorted into $\mathrm{CD}_{10}{ }^{-} \mathrm{CD} 27^{+}$(memory), $\mathrm{CD} 10^{-} \mathrm{CD} 27^{-} \mathrm{IgD}^{+}$(naïve), and $\mathrm{CD} 10^{-} \mathrm{CD} 27^{-} \mathrm{IgD}^{-}\left(\mathrm{IgD}^{-} \mathrm{CD} 27^{-} \mathrm{DN}\right.$ memory) B-cell and $\mathrm{CD} 10^{-} \mathrm{CD} 27^{+-}$(pre-GC/CG/plasma) cell populations using a FACSAria II high-speed cell sorter (BD Pharmingen) at $4{ }^{\circ} \mathrm{C}$ under sterile conditions. Post-sort analyses were performed to assess the purity of sorted cells. Peripheral blood mononuclear cells (PBMCs) from healthy donors (HD) were isolated by density-gradient centrifugation using Ficoll-Hypaque. Written consent was obtained from all blood donors.

\section{In-vitro cell culture and CFSE proliferation assay}

B cells were cultured in R10 medium at $37{ }^{\circ} \mathrm{C}$ and $5 \%$ $\mathrm{CO}_{2}$. For gene expression analyses, cells were enriched 
for $\mathrm{CD} 27^{-} \mathrm{CD} 10^{-} \mathrm{B}$ cells and plated at $3 \times 10^{6}$ cells per $\mathrm{ml}$ with preincubation for 1 hour at $37{ }^{\circ} \mathrm{C}$ with Emab $(5 \mu \mathrm{g} / \mathrm{ml})$ or hIgG1 isotype control $(5 \mu \mathrm{g} / \mathrm{ml}$; Sigma) or R10 medium and then stimulated with TLR7 agonist R848 (50 ng/ml; InvivoGen), $\mathrm{F}\left(\mathrm{ab}^{\prime}\right)_{2}$ anti-human IgM (5 $\mu \mathrm{g} / \mathrm{ml}$; Jackson ImmunoResearch Laboratories, Inc.), or a combination of R848 plus anti-IgM. In some cases, cells were pretreated with IFN- $\alpha$ at $1000 \mathrm{U} / \mathrm{ml}$ (PBL, Piscataway, NJ, USA). Samples were cultured for 12 hours, harvested, and used for RNA isolation. For cell proliferation experiments, cells were loaded with $2.5 \mu \mathrm{M}$ CFSE (ThermoFisher Scientific) in PBS at $37{ }^{\circ} \mathrm{C}$ for 10 min, quenched with R10 medium, washed, stimulated, and then cultured for 3 days. For assessing cell survival and plasma cell differentiation, sorted B-cell subsets were placed in 96-well plates at a concentration of $2.5 \times 10^{6}$ cells per ml, treated with different stimuli, and analyzed by flow cytometry after 3-5 days of in-vitro cell culture.

\section{Cytokine production}

B cells enriched for $\mathrm{CD} 10^{-} \mathrm{CD} 27^{-}$cells were plated at $5 \times 10^{6}$ cells per $\mathrm{ml}$ in 96-well plates, preincubated with or without Emab or a human IgG control, and stimulated with $\mathrm{R} 848$ and/or $\left.\mathrm{F}(\mathrm{ab})^{\prime}\right)_{2}$ anti-human IgM. Culture supernatants were collected 3 days post stimulation, frozen down, and used to assess cytokine production. Cytokine array (R\&D Systems) data showed significant induction of IL-6 and IL-10 after R848 and/or anti-IgM stimulation. Further quantification of these cytokines was performed using Human Quantikine ELISA Kits (R\&D Systems) according to the manufacturer's instructions.

\section{Flow cytometry}

For characterization of tonsillar B-cell subsets, single cell suspensions were stained with appropriate combinations of fluorescently labeled mAbs, including anti-CD10 (CBCALLA), CD19 (SJ25C1), CD20 (2H7), CD22 (4KB128 and S-HCL-1), CD27 (LG.7F9), CD38 (HB7) (eBioscience), IgD (IA6-2), CD3 (SP34-2), and CD95 (DX2) (BD Biosciences). Live cells were identified using LIVE/DEAD Fixable Near-IR staining (Molecular Probes) according to the manufacturer's instructions. Cultured cells were pelleted, washed, and stained with LIVE/DEAD, followed by surface staining with fluorescently labeled mAbs. For Blimp1 intracellular staining, cells were first stained with LIVE/DEAD fixable dye, washed, stained with appropriate surface markers, washed and then fixed, permeabilized, and stained with PE-conjugated rat IgG2ak anti-Blimp1 Ab (6D3) using the Transcription Factor Buffer Set (BD). CFSE-labeled cells were cultured for 3 days and the levels of cell proliferation were measured based on CFSE dilution. Multicolor flow cytometry was performed using a five-laser LSRII flow cytometer (BD) and analyzed with FlowJo software (Tree Star).

\section{Imaging flow cytometry}

Emab anti-CD22 binding and internalization by tonsillar B cells was assessed by multispectral imaging flow cytometry. Tonsillar B cells were stained with mAb specific for CD10, CD20, CD27, and IgD with or without Emab, conjugated to Pacific Blue (conjugation was performed using Pacific Blue $^{\text {tu }}$ Antibody Labeling Kit from Molecular Probes, ThermoFisher Scientific). Incubation with Pacific Blue-Emab was performed at either $4{ }^{\circ} \mathrm{C}$ on ice in the presence of $\mathrm{NaN}_{3}$ or at $37^{\circ} \mathrm{C}$ for $30 \mathrm{~min} . \mathrm{CD} 20^{+}$cells were gated into $\mathrm{CD} 10^{-} \mathrm{CD} 27^{-}, \mathrm{CD} 10^{-} \mathrm{CD} 27^{+}$, and $\mathrm{CD} 10^{-} \mathrm{CD} 27^{+/-}$B-cell subsets, and Emab binding and receptor-mediated internalization was determined for each subset. Then 50,000100,000 cells were analyzed using $60 \times$ camera magnification using an Image Stream X Mark II instrument and data were analyzed with IDEAS software (Amnis). The Internalization Score (IS) was defined as the ratio of intensity inside the cell to the intensity of the entire cell.

\section{Quantitative RT-PCR}

Total RNA was extracted from cells using an RNeasy mini kit with DNase treatment (QIAGEN). First-strand cDNA was generated using $250 \mathrm{ng}$ of total RNA with the SuperScript III high-capacity cDNA RT-kit using random primers (Invitrogen). Primers, as indicated in Additional file 1: Table S1, were synthesized (Invitrogen) and diluted to the appropriate concentrations using molecular-grade water. Transcript expression was analyzed by quantitative RT-PCR using $\mathrm{SYBR}^{\circ}$ green PCR Master Mix (Applied Biosystems) on an Applied Biosystems StepOnePlus Real Time PCR System using a twostage cycle of $95^{\circ} \mathrm{C}$ for $15 \mathrm{~s}$ and $60^{\circ} \mathrm{C}$ for 1 min repeated for 40 cycles, followed by a dissociation stage. Threshold cycle $(\mathrm{Ct})$ values were determined by setting a constant threshold at 0.2. All samples were normalized for the expression of 18S; fold changes in gene expression were calculated using the $2^{-\Delta \Delta \mathrm{CT}}$ method and presented as relative expression to unstimulated controls.

\section{Statistical analyses}

Graphs and statistical analyses were performed using Prism 5.0 software (GraphPad, San Diego, CA, USA). Statistical significance between groups was determined by two-tailed, unpaired Student's $t$ test or by one-way ANOVA with Turkey post test. Pearson's correlation was used to measure the relationship between two variables. Results are reported as mean \pm SD or \pm SEM. $p<0.05$ was considered statistically significant.

\section{Results}

CD22 is expressed broadly across tonsillar B-cell subpopulations and is internalized in response to Emab Human tonsils contain $50-60 \% \mathrm{CD}^{+} 9^{+}$cells and thus represent a useful source of $B$ cells, including cells with 
various phenotypes and activation states. Previous analyses showed that $60-80 \%$ of purified dense tonsillar B cells are $\mathrm{CD}_{22} 2^{+}$, including both $\mathrm{IgD}^{+}$and $\mathrm{IgD}^{-}$cells [59]. To determine the levels of CD22 expression on tonsillar B-cell subsets in more detail, we performed a multicolor flow cytometry analysis, using mAbs against CD19, CD10, CD27, IgD, CD38, and CD22. As Fig. 1a shows, $\mathrm{CD} 19^{+}$tonsillar B cells can be separated into three distinct populations based on their relative expression of $\mathrm{CD} 10$ and $\mathrm{CD} 27$ : first, $\mathrm{CD} 10^{-} \mathrm{CD} 27^{-}$cells, which consist mostly of naive $\mathrm{B}$ cells that are also $\mathrm{CD} 38^{\mathrm{lo}}$ and $\mathrm{IgD}^{+}$; and, second, a $\mathrm{CD} 10^{-} \mathrm{CD} 27^{+}$cell population comprised of memory B cells, including $\operatorname{IgD}^{-}$(switched) and $\operatorname{IgD}^{+}$ (unswitched) $\mathrm{CD}_{2} 7^{+}$cells. Counterparts of these two populations are found within the PBMC pool. A third, highly abundant population of $\mathrm{B}$ cells found in the tonsils but not in the blood is $\mathrm{CD} 10^{+} \mathrm{CD} 27^{-/+} \mathrm{CD} 38^{+}$, a heterogeneous population including pre-GC, GC, and post-GC (plasmablast/plasma cell) B cells $[60,61]$.
Surface staining with $\mathrm{CD} 22$ at $4{ }^{\circ} \mathrm{C}$ (to prevent receptor internalization) showed that $\mathrm{CD} 22$ was expressed on all B-cell subsets but that the $\mathrm{CD} 10^{-} \mathrm{CD} 27^{-} \mathrm{B}$ cells expressed higher levels of CD22 (average MFI 148) than $\mathrm{CD} 10^{-} \mathrm{CD} 27^{+}$memory B cells (MFI 120) or $\mathrm{CD} 10^{-}$ $\mathrm{CD}_{27^{-/+}}$(GC/plasma cell-associated) B cells (MFI 130) (Fig. 1b); however, these differences were not statistically significant. We also compared CD22 expression levels on $\mathrm{CD} 19^{+} \mathrm{CD} 10^{-} \mathrm{CD} 27^{-}$and $\mathrm{CD} 10^{-} \mathrm{CD} 27^{+}$tonsillar $\mathrm{B}$ cells to those of $\mathrm{CD} 19^{+} \mathrm{CD} 10^{-} \mathrm{CD} 27^{-}$and $\mathrm{CD} 10^{-} \mathrm{CD} 27^{+}$ blood $\mathrm{B}$ cells from healthy donors and found no significant differences.

Using imaging flow cytometry, we found that $\mathrm{CD} 10^{-}$ CD27- cells very efficiently and uniformly internalized Emab (IS between 0.8 and 0.9) (Fig. 1c). Consistent with CD22 expression data, a significant percentage of cells within the other two subsets (e.g., $\mathrm{CD} 10^{-} \mathrm{CD} 27^{+}$and $\mathrm{CD} 10^{+} \mathrm{CD} 27^{-/+}$cells) also internalized Emab (data not shown). Thus, human tonsils can be used to investigate

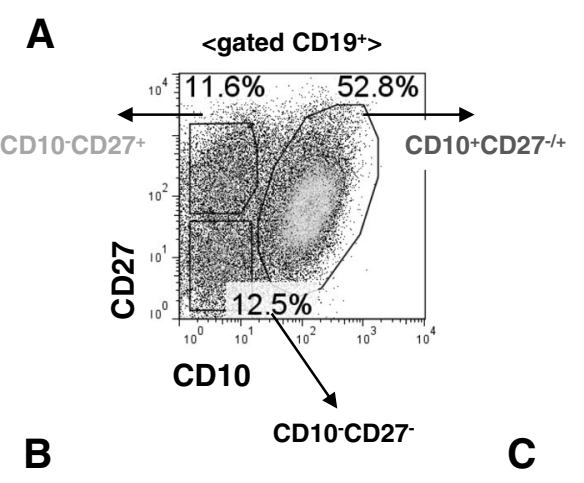

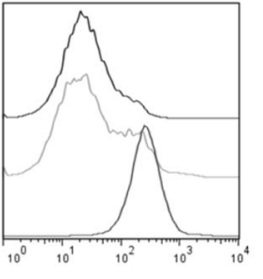

CD38

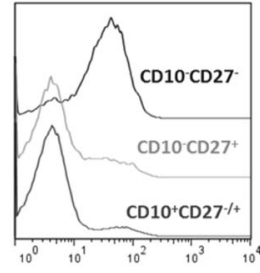

IgD
B

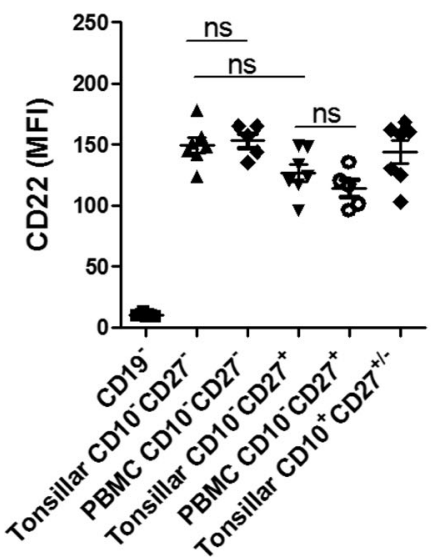

C

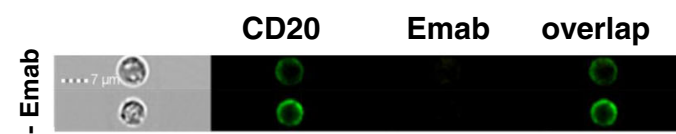

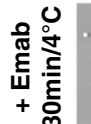
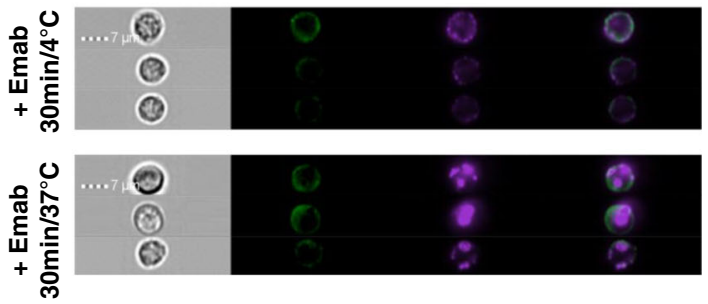

Fig. $1 \mathrm{CD}^{-} 7^{-} \mathrm{CD} 10^{-}$tonsillar B cells express CD22 and internalize Emab. a, b Characterization of tonsillar B-cell subsets. Tonsillar cells were stained with fluorochrome-labeled mAbs against CD10, CD19, CD22, CD27, CD38, and IgD and analyzed using multicolor flow cytometry. a Representative flow analysis of gated live CD19 ${ }^{+}$cells showing B-cell subgating into CD10 CD27, CD10-CD27 ${ }^{+}$, and CD10 ${ }^{+}$CD27 ${ }^{+/}$subsets; right histograms show expression of CD38 and IgD within each population. $\mathbf{b}$ Surface expression of CD22 quantified by flow cytometry and compared to corresponding B-cell subsets from PBMCs of healthy donors. Each dot on the graph represents individual donors. c Tonsillar B cells were stained with mAb specific for CD10, CD27, and CD20 (green) and with Emab, conjugated to Pacific Blue (purple). Cells were incubated at 4 or $37{ }^{\circ} \mathrm{C}$, and Emab surface binding and internalization of $\mathrm{CD} 10^{-} \mathrm{CD} 27^{-}$cells was visualized by imaging flow cytometry. Data shown are representative of three independent experiments. Emab epratuzumab, PBMC peripheral blood mononuclear cell 
the differential effects of $\mathrm{CD} 22$ crosslinking by Emab on the responses of B-cell subsets from human lymphoid tissue. In particular, the $\mathrm{CD} 19^{+} \mathrm{CD} 10^{-} \mathrm{CD} 27^{-} \mathrm{B}$ cells express high levels of CD22 and efficiently internalized Emab. Because this population likely corresponds to circulating $\mathrm{CD}^{2} 7^{-} \mathrm{B}$ cells that are significantly decreased upon Emab administration in vivo [54], we focused our study initially on this B-cell subset. We developed a protocol for enrichment of $\mathrm{CD} 10^{-} \mathrm{CD} 27^{-} \mathrm{B}$ cells using a two-step enrichment process, including rosetting and depletion of $\mathrm{CD}^{+}, \mathrm{CD}^{+}, \mathrm{CD}_{2} 7^{+}$, and $\mathrm{CD} 10^{+}$cells by magnetic bead separation. Using this protocol, we were able to consistently obtain $70-80 \%$ pure "untouched" $\mathrm{CD} 19^{+} \mathrm{CD} 20^{+} \mathrm{CD} 10^{-} \mathrm{CD} 27^{-}$B cells not bound by mAbs that might affect their responses (Additional file 2: Figure S1).

\section{Emab anti-CD22 does not affect the expression of BCR-} inducible genes and genes associated with TLR signaling In initial experiments, we used $\mathrm{CD} 20^{+} \mathrm{CD} 10^{-} \mathrm{CD} 27^{-}$ enriched $B$ cells to test the effects of Emab on responses to BCR and/or TLR7 stimulation. After enrichment, we preincubated cells for 1 hour at $37{ }^{\circ} \mathrm{C}$ with Emab, hIgG1 isotype control, or R10 medium and then stimulated them with the TLR7 agonist R848, F(ab')2 anti-human IgM, or a combination of R848 and anti-IgM for 12 hours. Using quantitative RT-PCR, we measured the relative expression of multiple genes known to be induced downstream of BCR signaling $\left(C-M Y C, B C L_{X L}\right.$, TP53) or associated with TLR7 signaling (TLR7, TLR9, MyD88, IRF7, UNC93B, IRAK4, TRAF6). Emab had no significant effect on the expression of any of these genes (Additional file 3: Figure S2 and data not shown).

\section{Emab modestly enhances B-cell proliferation}

To further study the effects of CD22 crosslinking by Emab on B-cell responses, we tested its effects on cell survival and cell proliferation. $\mathrm{CD} 10^{-} \mathrm{CD} 27^{-}$enriched $\mathrm{B}$ cells were labeled with CFSE and stimulated with $\mathrm{F}\left(\mathrm{ab}^{\prime}\right) 2$ antihuman IgM, the TLR7 ligand R848, or a combination of $\mathrm{F}\left(\mathrm{ab} \mathrm{b}^{\prime}\right) 2$ anti-human IgM and R848. Cells were cultured for 3 days and then analyzed for cell survival and proliferation by flow cytometry. Results from five independent experiments demonstrated a small but consistent enhancement of B-cell proliferation in response to anti-IgM plus R848 in the presence of Emab (Fig. 2a, b); Emab showed no effect on cell survival in culture (data not shown). Because B-cell differentiation into effector cells usually requires cell cycle exit, these data raised the possibility that Emab might affect other B-cell functions such as their ability to produce cytokines and differentiate into Ab-producing cells.

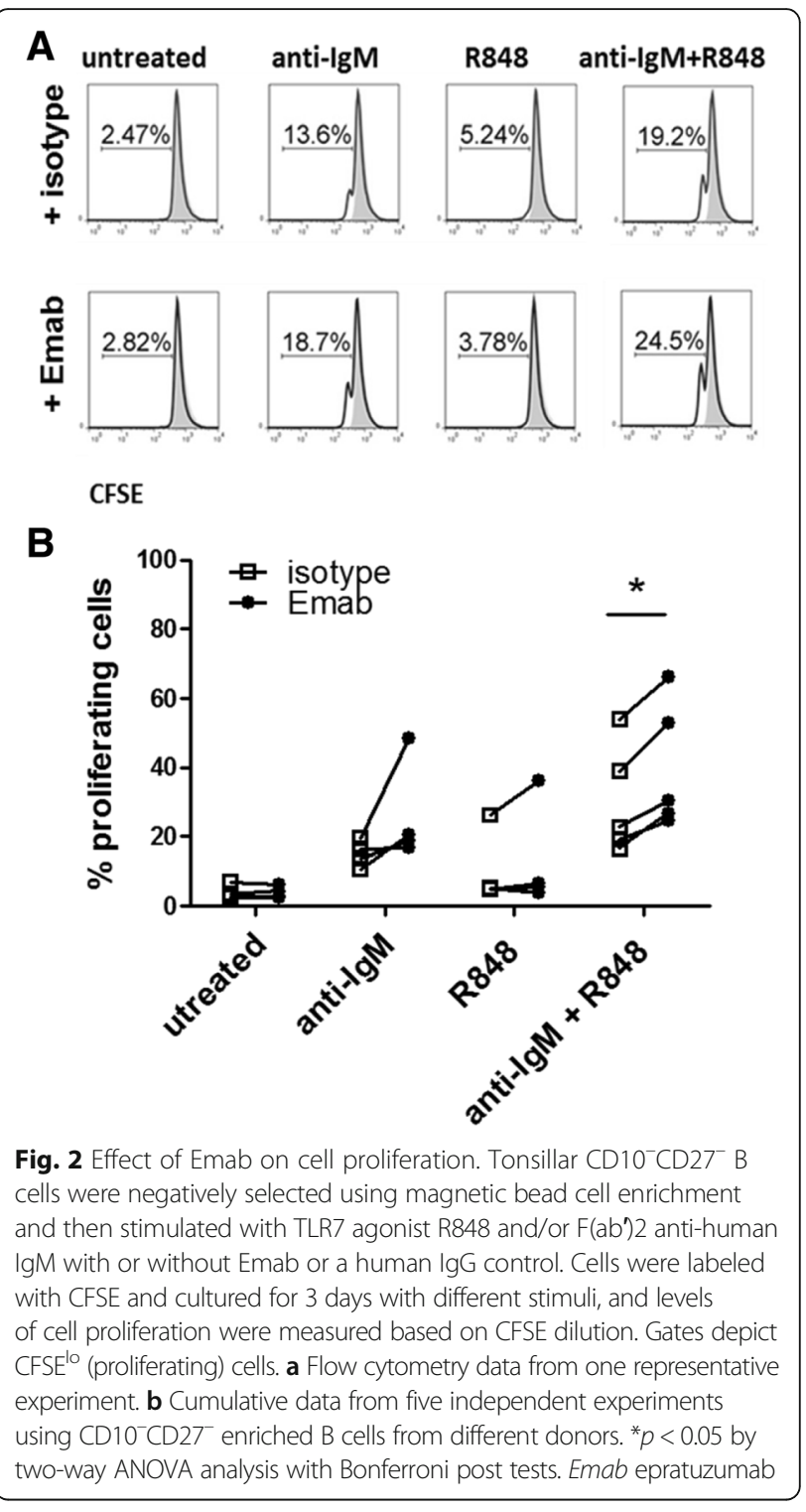

\section{Emab differentially regulates BCR and TLR7-induced cytokine production}

To test the effects of Emab on human BCR and TLR7induced cytokine production, we measured the level of cytokine/chemokine production in B cells cultured with or without Emab. In initial studies using cytokine arrays, we found that R848 or a combination of $F\left(\mathrm{ab}^{\prime}\right) 2$ anti-human IgM plus R848 stimulation of $\mathrm{CD} 10^{-} \mathrm{CD} 27^{-}$tonsillar B cells induced the production of several cytokines and chemokines, of which the most striking were IL-6 and IL-10. In a subsequent set of experiments, we isolated $\mathrm{CD} 10^{-} \mathrm{CD} 27^{-}$ tonsillar B cells from individual donors and measured the production of IL- 6 and IL-10 after 3 days of cell culture with or without Emab or a human IgG control by ELISA (Fig. 3a). In seven out of nine independent experiments, the production of IL-6 in response to R848 and/or anti-IgM 


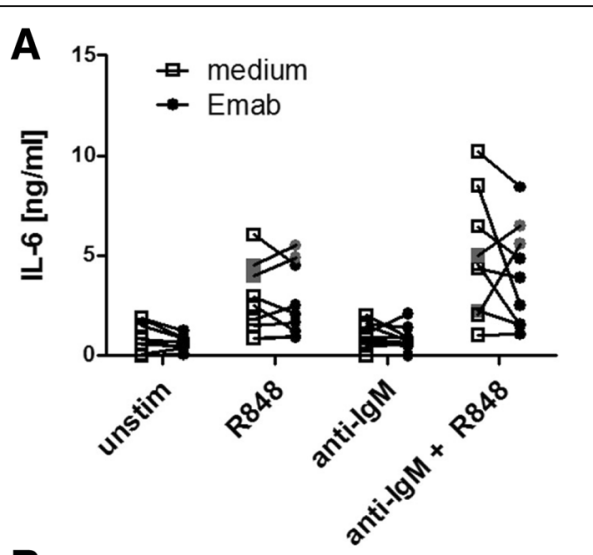

B

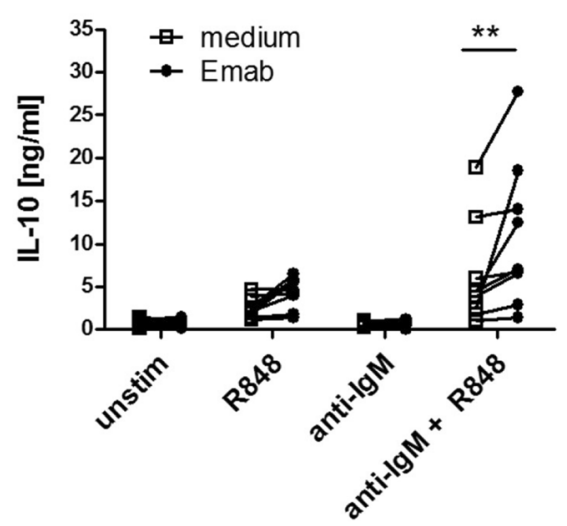

C $\quad 25] \quad \mathrm{R}=0.921$

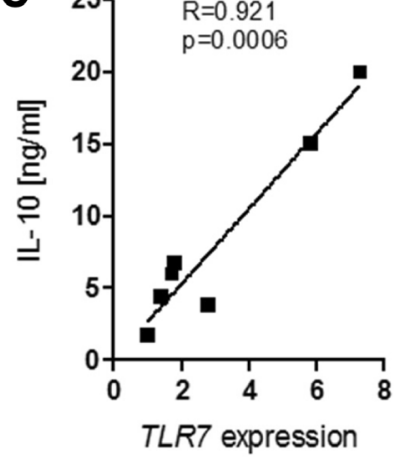

Fig. 3 Effects of Emab on IL-6 and IL-10 cytokine production. Tonsillar CD10-CD27- B cells were negatively selected using magnetic bead cell enrichment and then stimulated with R848 and/or F(ab')2 anti-human IgM with or without Emab or a human IgG control. $\mathbf{a}$, b Cells were treated with different stimuli and cultured for 3 days, and production of IL-6 and IL-10 in cell supernatants was quantified by ELISA. Cumulative data from nine independent experiments using CD10-CD27- B cells from different donors. Experiments with increased IL-6 production in the presence of Emab are shown (gray) (a). c Correlation between TLR7 mRNA expression in donor $C D 10^{-} \mathrm{CD} 27^{-}$B cells at the time of activation and the levels of IL-10 produced 3 days after anti-lgM/R848 stimulation. ${ }^{*} p<0.01$ by two-way ANOVA analysis with Bonferroni post tests. Emab epratuzumab, IL interleukin, TLR7 Toll-like receptor 7

plus R848 was reduced in the presence of Emab. However, two experiments showed the opposite effect (i.e., increased induction of IL-6).

Notably, the induction of IL-10 in response to anti-IgM/ TLR7 stimulation was significantly increased in the presence of Emab (Fig. 3b). Although the production of IL-10 varied between donors, interestingly this variation was principally due to donor variation in the expression of the TLR7 receptor (Fig. 3c). Priming of $\mathrm{CD} 10^{-} \mathrm{CD} 27^{-}$enriched $B$ cells with IFN- $\alpha$ led to a 3-fold to 4-fold increase in the expression of TLR7 and resulted in increased production of IL-10 after IgM/TLR7 stimulation, which in turn was further increased by Emab (Additional file 4: Figure S3A and Fig. $3 \mathrm{~b}$ ). Together, these data show that Emab has differential effects on cytokine production after BCR/TLR7 stimulation, by decreasing the production of the proinflammatory cytokine IL-6, but promoting the immunoregulatory cytokine IL-10. The observed heterogeneity of the responses to $\mathrm{BCR} / \mathrm{TLR} 7$ engagement largely reflects differences in the expression of TLR7.
Emab selectively inhibits the expression of PRDM1, the gene encoding Blimp1

To further determine the effects of Emab on B-cell activation and differentiation, we examined the expression of genes known to regulate $\mathrm{B}$-cell differentiation from naïve into Ab-producing cells. As shown in Fig. 4a, B-cell differentiation is regulated by a complex regulatory network, consisting of transcription factors that regulate the transcriptional activation (or repression) of one another as well as other key genes involved in B-cell differentiation [62]. Initially, we examined $\mathrm{CD} 10^{-} \mathrm{CD} 27^{-}$enriched $\mathrm{B}$ cells, which were preincubated with Emab, hIgG1 isotype control, or medium and then stimulated with R848, $\mathrm{F}\left(\mathrm{ab}^{\prime}\right)_{2}$ anti-IgM, or a combination of R848 and anti-IgM. These stimuli had no effect on the expression of MITF, BACH2, BCL6, PAX5, IRF4, or XBP1 either alone or with Emab (Fig. 4c and data not shown). However, stimulation with R848, anti-IgM, or a combination of the two induced a 5-fold to 15 -fold increase in the expression of PRDM1, the gene encoding Blymphocyte-induced maturation protein 1 (Blimp1). Emab 

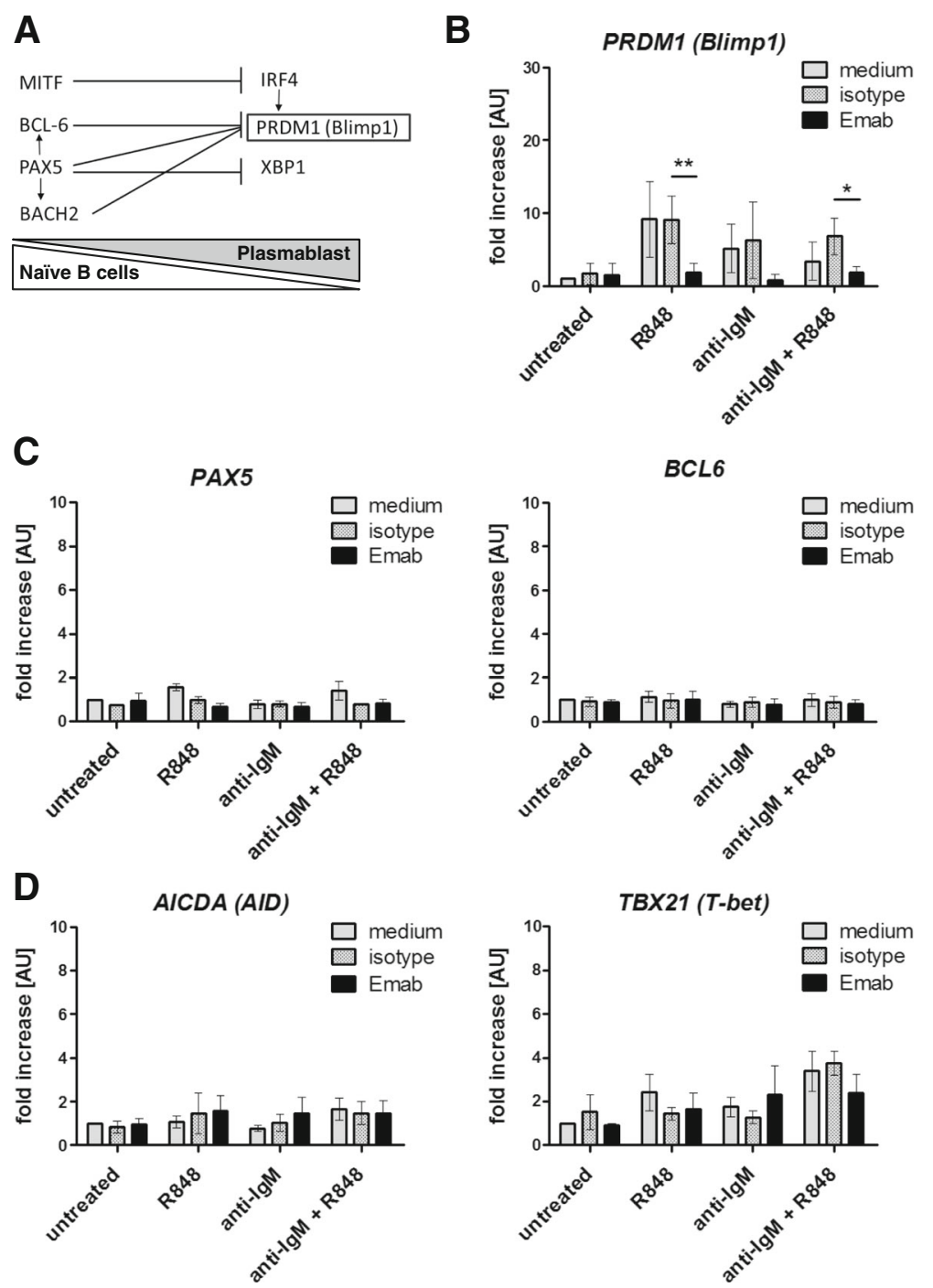

Fig. 4 Emab selectively inhibits PRDM1 mRNA expression in CD10-CD27- B cells. a Network of transcription factors involved in B-cell differentiation into Ab-producing cells. b-d Tonsillar CD10-CD27- B cells were negatively selected using magnetic bead cell separation and then stimulated with R848 (TLR7 agonist) and/or F(ab')2 anti-human IgM with or without Emab or a human lgG control. RNA was isolated 12 hours after stimulation and expression of different genes was quantified by RT-PCR. ${ }^{*} p<0.05,{ }^{*} p<0.01$ as determined by two-way ANOVA with Bonferroni post test. Emab epratuzumab

dramatically inhibited PRDM1 mRNA levels, leading to an almost complete suppression of the induction of this gene after stimulation (Fig. 4b). Although we observed some variation in the increase of PRDM1 levels, the inhibitory effect of Emab was consistently seen in six independent experiments. Remarkably, this effect appeared to be quite selective because Emab showed no significant effect on the expression of other genes involved in B-cell differentiation and immunoglobulin class-switching, including AICDA (encoding activation-induced deaminase) or TBX21 (encoding T-box transcription factor, T-bet) (Fig. 4d). Thus, we conclude that signaling downstream of CD22 induced by Emab selectively inhibits PRDM1 expression in response to TLR7 and BCR stimulation. Because Blimp1 is a key transcription factor, required by $\mathrm{B}$ cells to mature into Ab-producing cells, we propose that Emab might also prevent B-cell differentiation into (auto-)Ab-producing cells.

\section{Emab inhibits the activation and differentiation of a subset of $B$ cells: $C D 27^{-} \lg D^{-}$(DN memory) $B$ cells that are highly responsive to TLR7 stimulation}

Although $\mathrm{CD} 10^{-} \mathrm{CD} 27^{-} \mathrm{B}$ cells are mostly thought to consist of $\operatorname{IgD}^{+}$naïve $\mathrm{B}$ cells, recent reports have identified a population $\mathrm{CD}^{2} 7^{-} \mathrm{IgD}^{-}$cells that have the properties of memory B cells $[4,5,7]$. These $\mathrm{CD}^{2} 7^{-} \mathrm{IgD}^{-} \mathrm{DN}$ memory B cells are found in the peripheral blood and tonsils of healthy donors, but their frequency is significantly increased in patients with SLE [5]. Furthermore, an expansion of activated $\left(\mathrm{CD}^{+} 5^{+}\right) \mathrm{DN}$ memory cells was found to correlate with SLE disease activity $[4,5]$. 
DN memory B cells are also highly responsive to stimulation through TLR9 by CpG [4]. This led us to hypothesize that $\mathrm{IgD}^{-}$cells within the $\mathrm{CD} 10^{-} \mathrm{CD} 27^{-}$ population might be a subset that responds to TLR7 stimulation by upregulating PRDM1.

To address this question, we first assessed whether the tonsillar $\mathrm{CD} 10^{-} \mathrm{CD} 27^{-}$B-cell subset contained $\mathrm{DN}$ memory B cells using a combination of CD19, CD27, CD10, IgD, and CD95 surface markers. As expected, we found that the majority of $\mathrm{CD} 10^{-} \mathrm{CD} 27^{-}$cells expressed IgD; however, a population of $\operatorname{IgD}^{-} \mathrm{B}$ cells including $\mathrm{IgD}^{-} \mathrm{CD}^{+} 5^{+}$(activated $\mathrm{DN}$ memory) cells was also present in this fraction (Fig. 5a). Analysis of tonsillar B cells from nine different donors showed that $\mathrm{IgD}^{-} \mathrm{CD} 95^{+} \mathrm{B}$ cells represented $2.5-24 \%$ of the $\mathrm{CD} 19^{+} \mathrm{CD} 10^{-} \mathrm{CD} 27^{-}$population (Fig. 5a, b). Thus, we concluded that $\mathrm{CD}^{2} 7^{-} \mathrm{IgD}{ }^{-}$(DN memory) $\mathrm{B}$ cells (including $\mathrm{CD}^{+} 5^{+}$, activated $\mathrm{DN}$ cells) are found in the tonsillar $\mathrm{CD} 10^{-} \mathrm{CD} 27^{-}$fraction and might contribute to $\mathrm{CD} 19^{+} \mathrm{CD} 10^{-} \mathrm{CD} 27^{-}$B-cell responses to TLR7.

To further test the effects of anti-IgM and TLR7 stimulation on DN memory B cells and determine whether or not Emab might affect their differentiation, we isolated highly purified $\mathrm{CD} 19^{+} \mathrm{CD} 10^{-} \mathrm{CD} 27^{-} \mathrm{IgD}^{-}$(DN memory) and $\mathrm{CD} 19^{+} \mathrm{CD} 10^{-} \mathrm{CD} 27^{-} \mathrm{IgD}^{+}$(naïve) $\mathrm{B}$ cells using cell sorting (detailed sorting strategy and post-sort cell analysis are presented in Additional file 5: Figure S4) and then stimulated the cells with R848, F(ab')2 anti-IgM, or a combination of R848 and anti-IgM in the presence of Emab or isotype control. Five days later, we analyzed the cells for expression of CD27 and CD38 and for survival. As Fig. 6a shows, $\mathrm{CD}^{-} 0^{-} \mathrm{CD} 27^{-} \mathrm{IgD}^{-}$(DN memory) cells but not $\mathrm{CD}^{-} 0^{-} \mathrm{CD} 27^{-} \mathrm{IgD}^{+}$(naïve) $\mathrm{B}$ cells responded to stimulation through TLR7, as evidenced by the appearance of $\mathrm{CD} 38^{\text {hi }} \mathrm{CD} 27^{\mathrm{hi}}$ activated cells. Cumulative data from five independent experiments showed that the TLR7-mediated activation of DN memory cells was significantly reduced in the presence of Emab (Fig. 6b). However, Emab did not affect cell survival of either DN memory or naïve B cells (Fig. 6c).

Consistent with Emab inhibition of the upregulation of PRDM1 mRNA levels in response to anti-IgM/TLR7 stimulation, the levels of Blimp1 protein within the $\mathrm{CD}^{-}{ }^{-} \mathrm{CD} 27^{-} \mathrm{IgD}^{-}$(DN memory) subset were significantly lower in the presence of Emab (Fig. 7). As expected, stimulation of cells with R848 alone or anti-IgM plus R848 led to a significant upregulation of the Blimp1 levels (MFI for the R848-treated samples $=11,866.7 \pm$ 2106.1), whereas the Blimp1 levels in the Emabpretreated samples were only modestly increased (MFI for the R848-treated samples $=4773.3 \pm 253.2)$ and significantly lower compared to the isotype-treated samples (Fig. 7a).

We found that DN memory cells also differentiated into $\mathrm{CD} 2 \mathrm{O}^{\mathrm{lo}} \mathrm{Blimp}^{+}$cells upon stimulation with either R848 alone or in combination with anti-IgM. These $\mathrm{CD} 20^{\mathrm{lo}} \mathrm{Blimp}^{+}$cells also expressed high levels of CD38 and CD27, but did not express CD138 (data not shown), suggesting that they most probably represent a population of plasmablasts or preplasma cells.

The frequencies of $\mathrm{CD} 20^{\mathrm{lo}} \mathrm{Blimp}^{+}$were markedly reduced in the presence of Emab (Fig. 7b, c), further suggesting that Emab might suppress their differentiation.

Together, these data demonstrate that tonsillar $\mathrm{CD} 27^{-}$ $\mathrm{IgD}^{-}$(DN memory) $\mathrm{B}$ cells found within the $\mathrm{CD}^{-} 0^{-}$ $\mathrm{CD}^{-} 7^{-}$cell fraction are highly responsive to TLR7
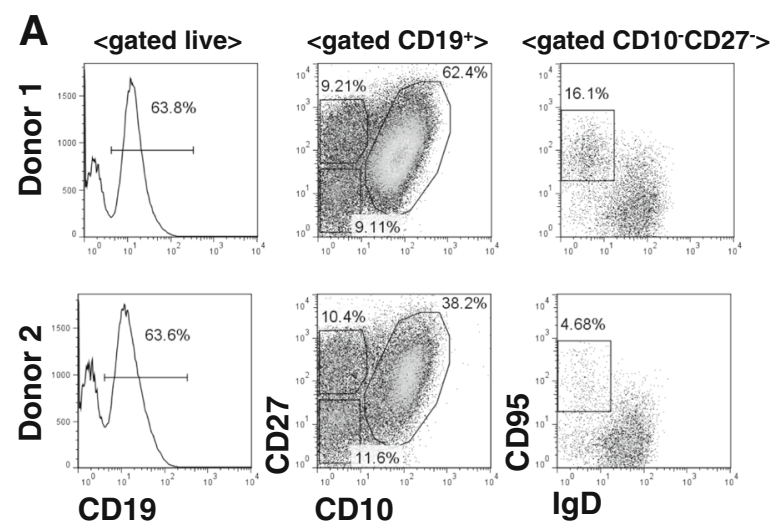

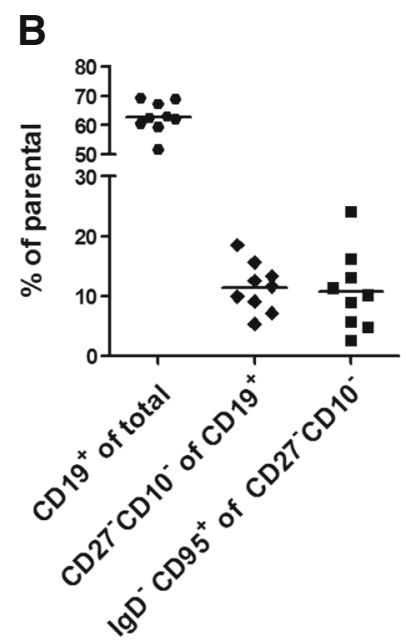

Fig. 5 Characterization of $C D 27^{-} \lg D^{-}$(DN memory) cells within tonsillar $C D 10^{-} C D 27^{-}$population. a Representative results from flow analysis of tonsils from two individual donors. Cells were stained with a combination of mAbs against CD19, CD27, CD10, IgD, and CD95 surface markers and used to determine the frequencies of $\operatorname{lgD} \mathrm{CD}^{-} 5^{+}$cells within the $\mathrm{CD} 19^{+} \mathrm{CD} 10^{-} \mathrm{CD} 27^{-}$cell fraction. $\mathbf{b}$ Frequencies of different cell subsets in tonsils from nine individual donors, showing significant variation in the frequencies of DN cells 

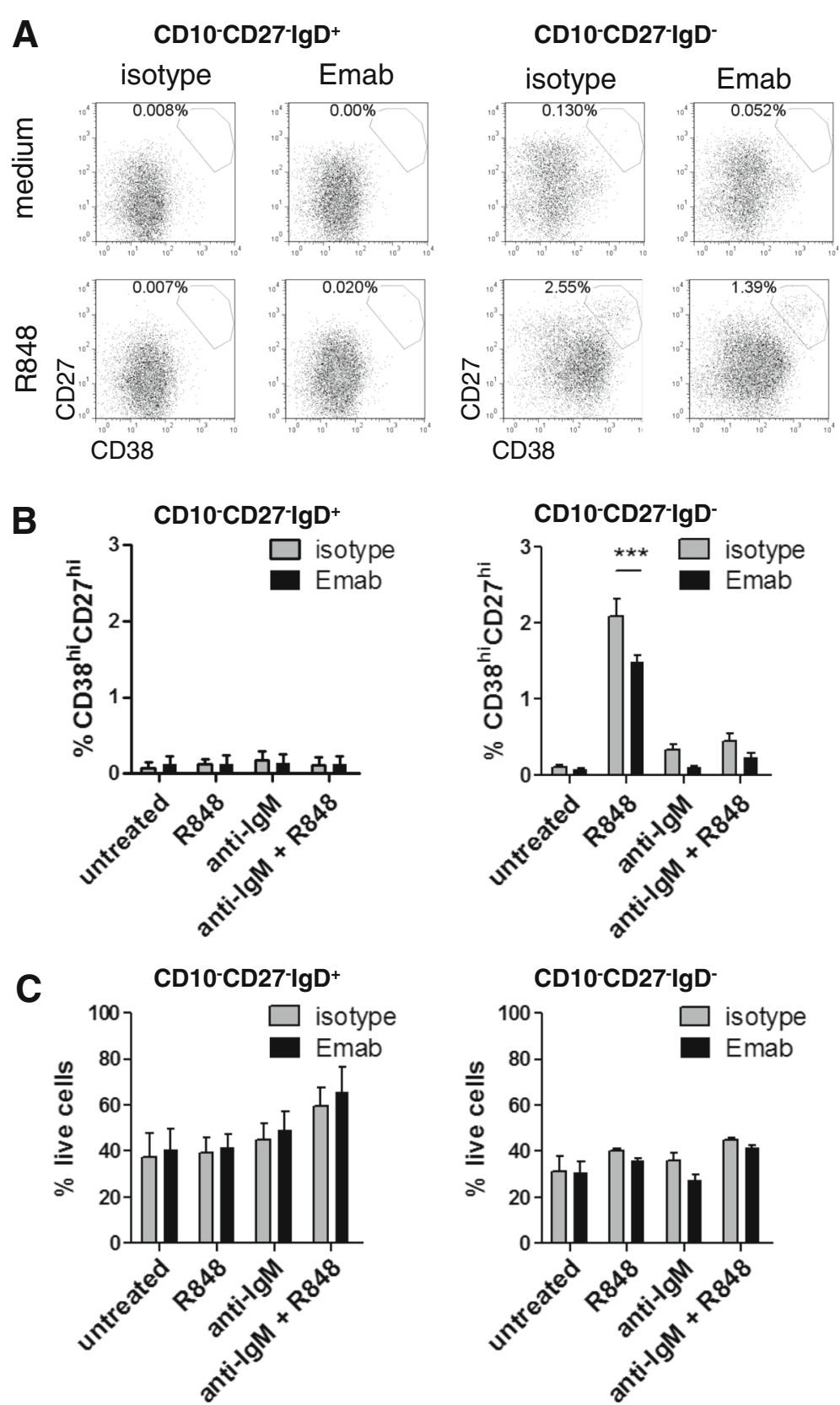

Fig. 6 Emab inhibits the activation $C D 27^{-} \mathrm{CD} 10^{-} \lg \mathrm{D}^{-}$(DN) B cells in response to TLR7 stimulation. $\mathrm{CD} 10^{-} \mathrm{CD} 27^{-} \lg D^{+}$(naïve) and $\mathrm{CD} 10^{-} \mathrm{CD} 27^{-} \operatorname{lgD}$ (DN memory) B-cell subsets were sorted and left untreated or stimulated with R848, anti-human F(ab')2 IgM, or a combination of R848 plus anti-IgM in the presence of Emab or isotype control Ab. Cells were cultured for 5 days and then cell viability and surface expression of CD38 and CD27 and cell frequencies of live cells were analyzed by flow cytometry. a Flow data show results from one representative experiment. Gates depict the frequencies of $\mathrm{CD} 27^{\text {hi }} \mathrm{CD} 38^{\text {hi }}$ (activated) cells in each subset (b, c) Cumulative data from five experiments using tonsils from different donors showing the percentage of $\mathrm{CD} 27^{\text {hi }} \mathrm{CD} 38^{\text {hi }}$ of gated live cells $(\mathbf{b})$ or the frequencies of live cells in culture (c). Tonsils used in these experiments were preanalyzed and selected to contain $>10 \% \mathrm{CD}^{+} 5^{+} \operatorname{lgD}{ }^{-}$or $\mathrm{CD} 27^{-} \mathrm{CD} 10^{-}$cells. ${ }^{* * *} p<0.001$, as determined by two-way ANOVA with Bonferroni post test. Emab epratuzumab

signals and, upon stimulation, can differentiate into plasmablast/preplasma cells. Consistent with the effects of inhibiting the expression of PRDM1, Blimp1 levels and Blimp1 ${ }^{+}$cells were significantly reduced in the presence of Emab.

\section{Emab affects the survival and differentiation of} $\mathrm{CD} 10^{+} \mathrm{CD} 27^{-/+}$cells

To further explore the effects of Emab on different Bcell populations in tonsils, we purified $\mathrm{CD} 10^{-} \mathrm{CD} 27^{+}$ (memory) and $\mathrm{CD} 10^{+} \mathrm{CD} 27^{-/+}$(pre-GC/CG/plasma) 

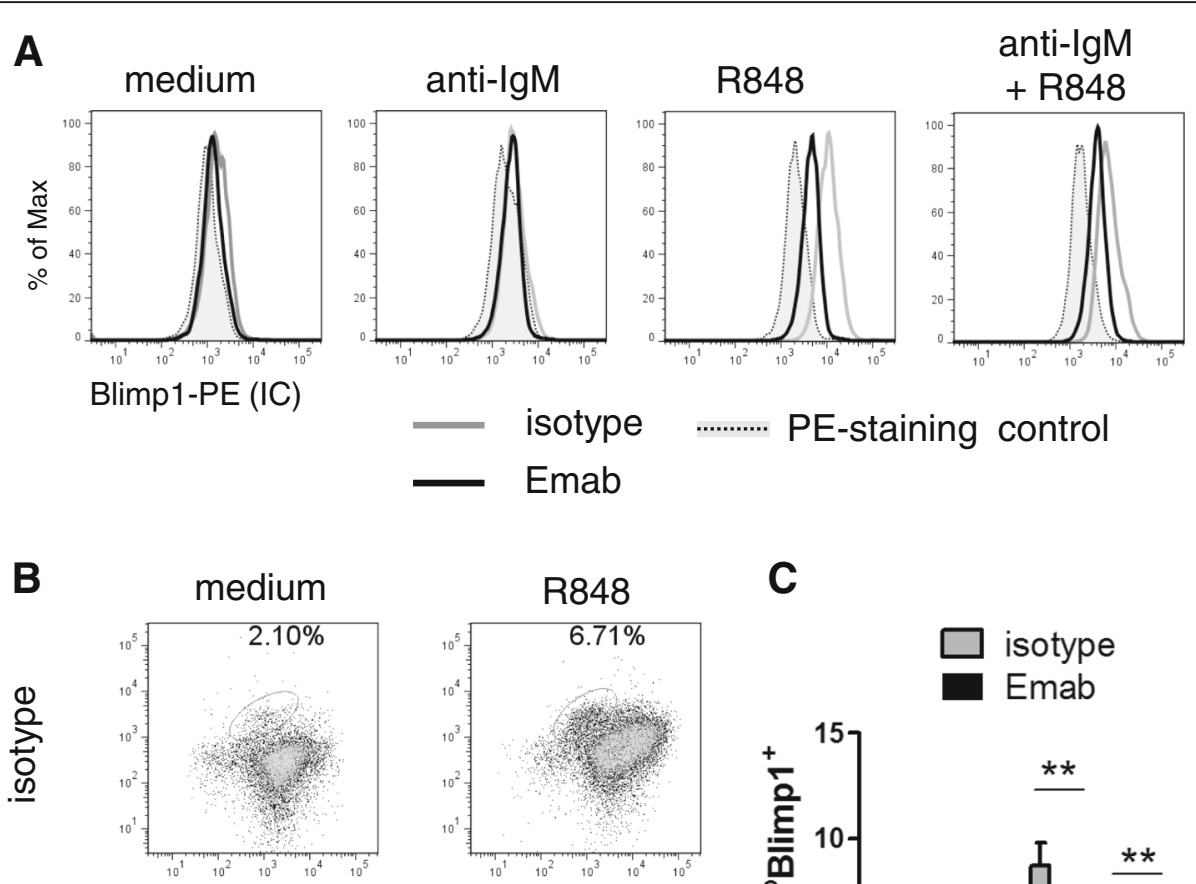

C
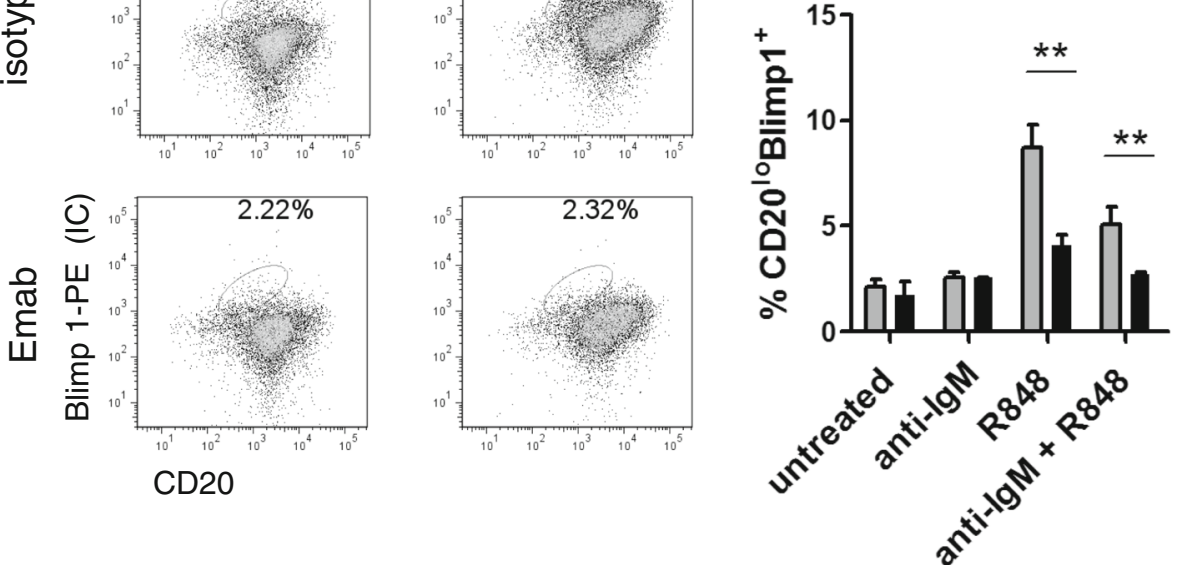

Fig. 7 Emab inhibits the generation of Blimp $1^{+}$cells. Sorted $C D 19^{+} C D 10^{-} C D 27^{-} \lg D^{-}$tonsillar B cells were left untreated or stimulated with R848, anti-human $\left.\mathrm{F}(\mathrm{ab})_{2}\right)_{2}$ IgM or a combination of R848 plus anti-lgM in the presence of Emab or isotype control Ab. a Representative flow cytometry data, showing intracellular Blimp1 expression within $\mathrm{CD}^{10^{-} \mathrm{CD} 27^{-} \mathrm{IgD}} \mathrm{D}^{-} \mathrm{B}$ cells after 3 days of cell culture in the presence of Emab (black line) or an isotype-matched control Ab (gray line). PE-conjugated rat lgG2a was used as a staining control (dotted tinted line). b Representative flow cytometry data showing $\mathrm{CD} 20$ and intracellular Blimp1 expression within $\mathrm{CD} 10^{-} \mathrm{CD} 27^{-} \mathrm{lgD} \mathrm{D}^{-}$cells after 3 days of cell culture. Gates depict frequencies of $\mathrm{CD} 2 \mathrm{O}^{\mathrm{lo}} \mathrm{Blimp} 1^{+}$cells. c Summary results from three independent experiments showing the percentage of CD20 ${ }^{\mathrm{lo}} \mathrm{Blimp} 1^{+}$from total live cells in culture after cell stimulation in the presence or absence of Emab. ${ }^{* *} p<0.01$, as determined by unpaired Student's $t$ test. Emab epratuzumab

cells and, as in the earlier described experiments, stimulated them with $\mathrm{R} 848, \mathrm{~F}\left(\mathrm{ab}^{\prime}\right)_{2}$ anti-hIgM, or a combination of R848 plus anti-IgM in the presence of Emab or isotype control. Cells were analyzed for the appearance of $\mathrm{CD} 38^{\text {hi }} \mathrm{CD} 27^{\text {hi }}$ activated cells and cell survival after 5 days of in-vitro culture. We found that Emab did not affect the responses of $\mathrm{CD} 10^{-} \mathrm{CD} 27^{+}$cells, but did significantly inhibit the activation/differentiation of $\mathrm{CD} 10^{+} \mathrm{CD} 27^{-/+}$ cells in response to R848, or a combination of R848 and anti-IgM, as measured by a greater than 2-fold reduction in the frequencies of $\mathrm{CD} 38^{\mathrm{hi}} \mathrm{CD} 27^{\mathrm{hi}}$ cells (Fig. 8a). Analysis of cell viability showed a significant reduction in the percentage of live cells within the $\mathrm{CD} 10^{+} \mathrm{CD} 27^{-1+}$ population in the presence of Emab, with or without stimulation. This effect of Emab seems specific to this particular cell population, because the survival of $\mathrm{CD} 10^{-}$ $\mathrm{CD}^{2} 7^{+}$(Fig. 8a), $\mathrm{CD} 10^{-} \mathrm{CD}^{-} 7^{-} \mathrm{IgD}^{-}$(DN memory), or $\mathrm{CD}^{-} 0^{-} \mathrm{CD} 27^{-} \mathrm{IgD}{ }^{+}$(naïve) B cells (Fig. 6c) was unaffected by Emab. Because the $\mathrm{CD} 10^{+} \mathrm{CD} 27^{-/+}$subset represents a heterogeneous population of $\mathrm{B}$ cells, further studies are needed to determine what cells within this mixed population are affected most by Emab. Together, these results demonstrate that, depending on the B-cell developmental/ maturation state, CD22 crosslinking by Emab can differentially affect B-cell survival and activation.

\section{Discussion}

A number of recent studies have demonstrated that TLR signaling in B cells plays an important role in modulation of B-cell effector functions such as cytokine 


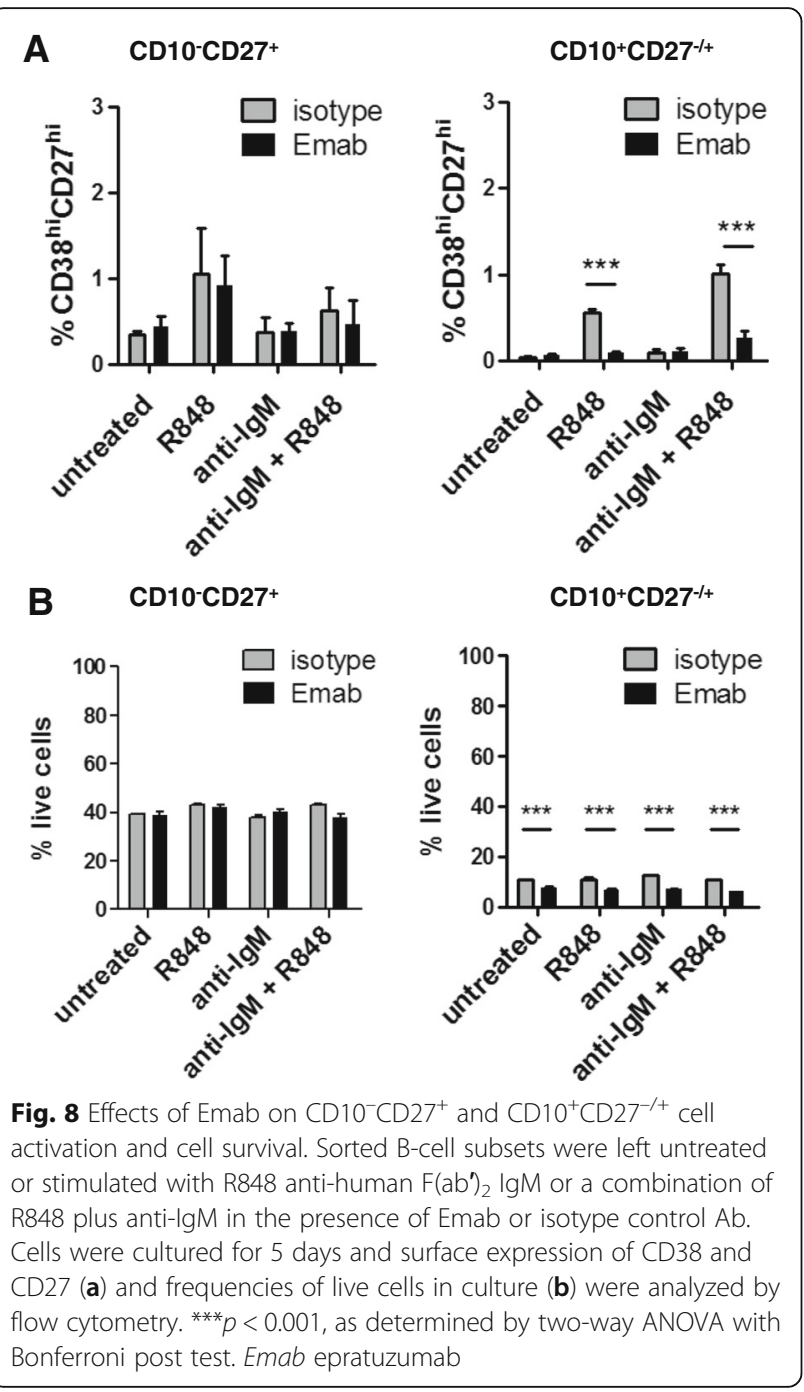

production and ability to produce auto-Abs [13]. Activation of B cells by TLR7 in particular has been proposed to play an important role in SLE [17, 20,63]. Because of the significance of TLR7 in the pathogenesis of SLE, we assessed how targeting CD22 with Emab affected B-cell responses after TLR7 and/or BCR stimulation. We used human tonsillar B cells, which provided the means to investigate the responses of $\mathrm{B}$ cells from different developmental/activation stages.

In our initial studies, we used tonsillar $\mathrm{CD} 20^{+} \mathrm{CD} 10^{-}$ $\mathrm{CD}^{-} 7^{-}$enriched $\mathrm{B}$ cells, which in many respects resemble $\mathrm{CD}^{-} 7^{-}$naïve blood B cells [64]. Because Emab has previously been shown to modulate signaling downstream of the BCR $[48,49,57]$, we investigated whether Emab might also affect the expression of genes known to be activated through the BCR. While BCR or TLR7 stimulation or a combination of the two stimuli induced upregulation of a number of genes, including $c M Y C$ and $B C L_{X \mathrm{~L}}$, Emab did not affect their expression. Similarly,
Emab showed no significant effect on the expression of TLR7 and TLR9 or of MyD88 and IRF7 genes that encode proteins downstream of TLR7 signaling. In another set of experiments, naïve tonsillar B cells were incubated with IFN- $\alpha$ or a combination of IFN- $\alpha$ and anti-IgM. While this stimulation led to a significant upregulation of multiple genes, and in particular those involved in TLR signaling, the expression of these genes was not affected by Emab (data not shown).

However, TLR7/BCR-driven IL-6 and IL-10 cytokine production by $\mathrm{CD} 20^{+} \mathrm{CD} 10^{-} \mathrm{CD} 27^{-} \mathrm{B}$ cells were differentially modulated by Emab with a significant increase in IL-10 production and an overall inhibition of IL-6. Analysis of IL-6 and IL-10 transcripts 6, 12, or 24 hours after TLR7/BCR stimulation showed no significant effect of Emab on gene expression (data not shown); IL-10 mRNA expression was only weakly increased after TLR7/BCR stimulation and again was not affected by Emab. Thus, the exact mechanism for Emab-induced modulation of cytokine production remains to be determined. Recently, Fleischer et al. [56] analyzed the effects of Emab on the cytokine production by purified total blood B cells from healthy donors and SLE patients. They found that Emab significantly decreased the expression of TNF- $\alpha$ and IL- 6 in response to anti-BCR and/or anti-BCR/CpG stimulation. Although anti-BCR/ CpG stimulation also induced significant increase of IL10 production, the authors found that IL-10 levels were not affected by Emab.

In contrast, we found that Emab significantly enhanced IL-10 production by naïve tonsillar B cells in response to anti-IgM/TLR7 stimulation. Interestingly, the capacity of B cells to produce IL-10 correlated positively with the expression levels of TLR7 at the time of stimulation. In this regard, we found that prestimulation of the cells with IFN- $\alpha$, a known inducer of TLR7 [26], was able to boost IL-10 production, which was further enhanced in the presence of Emab. The disparity between our results and those of Fleisher et al. [56] may be due to different sources of B cells being tested, use of a TLR7 vs a TLR9 agonist, and/or the levels of TLR9 or TLR7 in the B cells that were examined. We observed that IL-10 production was largely dependent on TLR7 activation by R848 and less dependent on BCR activation, a similar conclusion reached by Fleischer et al. although that they used a TLR9 ligand. In summary, in the majority of our experiments, Emab displayed a differential effect on cytokine production by suppressing IL-6 and inducing IL-10.

The effects of Emab on cytokine production may contribute to the understanding of the mode of action of Emab in vivo, particularly in autoimmune diseases, where B-cell-produced cytokines are believed to play an important role in driving or suppressing the disease [1]. For example, IL-6 has been implicated in B-cell 
differentiation and $\mathrm{Ab}$ production $[65,66]$, and is also known to cooperate with IL-21 to promote the differentiation of $\mathrm{CD}^{+}$T-follicular helper cells [67-70]. Furthermore, increased IL-6 levels have been reported in SLE patients with active disease and more recently IL-6 has been identified as a major genetic risk factor for SLE [71]. Emab-mediated IL-6-inhibition could possibly suppress inflammation associated with SLE. IL-10, on the contrary, is known to be produced by regulatory B cells [72] and has been proposed to suppress effector Th1 and Th17 cell responses [73-75]. Recent studies have suggested that IL-10 production by B cells might be defective in SLE patients [74, 76]. Based on our findings, CD22 engagement by Emab may very well help to reprogram B cells in SLE patients to restore IL-10 production.

Further studies are required to determine how CD22 signaling promotes IL-10 production by TLR7-driven B cells. Liu et al. [77] have recently shown that activation of STAT3 and ERK is required for TLR-induced IL-10 production by human B cells. The authors also found that IFN- $\alpha$ enhanced TLR7/8-induced but not TLR9induced IL-10 production. Although it is well known that TLR stimulation elicits IL-10 production, to our knowledge this study is the first to show a role for CD22 in promoting IFN- $\alpha$ /TLR7-induced IL-10 production. Whereas CD22 is often described as a negative regulator of BCR signaling, it should be noted that previous studies have shown that CD22 associates with a number of signaling molecules, such as Syk, PI-3 kinase, Grb2, and phospholipase-C $\mathrm{2} 2$ [78-80], and that direct CD22 engagement can induce activation of ERK2 [81]. In line with this finding, we have found that Emab induces increased ERK phosphorylation in human B cells [82]. In light of Liu et al.'s findings [77], this might provide a mechanistic explanation of how CD22 crosslinking by Emab promotes IL-10 production.

Interestingly, Emab also modestly increases B-cell proliferation in response to BCR/TLR7 stimulation. This effect of Emab might be selective to the $\mathrm{CD} 27^{-} \mathrm{CD} 10^{-}$ (naïve and $\mathrm{DN}$ ) cells and also dependent on the particular signals used to activate the cells. In contrast to CD27- (naïve/DN) B cells, Emab did not affect cell proliferation of $\mathrm{CD}^{2} 7^{+}$(classical memory) cells; however, the rates of cell proliferation were variable between different donors (data not shown). Previous studies have shown that Emab can inhibit the proliferation of $\mathrm{CD}^{2} 7^{-}$and $\mathrm{CD} 27^{+}$blood B cells in response to IL-2, IL-10, F(ab') and/or CD40L and CpG [54]. Thus, the effect of Emab on cell proliferation among various B-cell subsets needs further investigation. In the context of BCR/TLR7 stimulation of the $\mathrm{CD} 27^{-} \mathrm{CD} 10^{-}$subset, the small increase of cell proliferation may be related to our finding that Emab inhibits B-cell differentiation. Previous studies have shown that $B$ cells exit the cell cycle once they start to differentiate into Ab-producing plasma cells and a change in the expression of several transcription factors (e.g., a decrease of BCL6, PAX5, and c-Myc levels and an increase of Blimp1 expression) has been implicated in the transition/differentiation of naïve $B$ cells into plasma cells [62]. In $\mathrm{CD} 10^{-} \mathrm{CD} 27^{-} \mathrm{B}$-cell cultures, we found that Emab dramatically inhibited the levels of PRDM1, the gene encoding Blimp1, which was induced in response to TLR7 and/ or BCR/TLR7 stimulation. This effect of Emab was highly specific to PRDM1 because this Ab did not affect the expression of other genes involved in B-cell differentiation or immunoglobulin class-switching, including $M I T F$, $B A C H 2$, BCL6, PAX5, IRF4, XBP1, AICDA, or TBX21. We did see a trend toward reduction in the increase TBX21 in response to anti-IgM/TLR7 in the presence of Emab, but the combined results from different experiments did not show statistical significance.

The responses of human B-cell subsets to TLR7 or anti-BCR/TLR7 stimulation have not been studied in detail. Recently, Simchoni et al. [28] showed that TLR7 stimulation expands $\mathrm{IgM}^{+} \mathrm{CD} 27^{+}$memory $\mathrm{B}$ cells and promotes the generation of $\mathrm{CD} 27^{\text {hi }} \mathrm{B}$ cells. In the current study, by comparing four different B-cell populations based on the appearance of $\mathrm{CD} 38^{\mathrm{hi}} \mathrm{CD} 27^{\mathrm{hi}}$ cells, we discovered that the $\mathrm{CD} 10^{-} \mathrm{CD} 27^{-} \mathrm{IgD}{ }^{-}$subset was the most responsive to TLR7 stimulation compared to the other B-cell subsets. Notably, the generation of $\mathrm{CD} 38^{\text {hi }} \mathrm{CD} 27^{\text {hi }}$ cells was inhibited in the presence of Emab. A portion of $\mathrm{CD} 10^{+} \mathrm{CD} 27^{+}$and $\mathrm{CD} 10^{+} \mathrm{CD} 27^{-/+} \mathrm{B}$ cells also differentiated into $\mathrm{CD} 38^{\mathrm{hi}} \mathrm{CD} 27^{\mathrm{hi}}$ cells, but their frequencies were lower compared to those generated by $\mathrm{CD} 10^{-} \mathrm{CD} 27^{-} \mathrm{IgD}^{-}$B cells. Emab clearly decreased $\mathrm{CD} 38^{\mathrm{hi}} \mathrm{CD} 27^{\mathrm{hi}}$ cell frequencies, particularly within the $\mathrm{CD} 10^{+} \mathrm{CD} 27^{-/+}$cells. $\mathrm{CD} 10^{-} \mathrm{CD} 27^{-} \mathrm{IgD}{ }^{+}$ (naïve) B cells did not generate $\mathrm{CD} 38^{\text {hi }} \mathrm{CD} 27^{\text {hi }}$ cells in response to TLR7 stimulation. Of note, there were no significant differences in TLR7 expression between $\mathrm{CD}^{-} 0^{-} \mathrm{CD} 27^{-} \mathrm{IgD}{ }^{-}$and $\mathrm{CD}^{-} 0^{-} \mathrm{CD} 27^{-} \mathrm{IgD}^{+} \mathrm{B}$ cells, suggesting that their differential responsiveness to TLR7 ligation cannot be simply attributed to increased TLR7 levels. Furthermore, a comparison between these two cell populations showed no differences in their CD22 expression and/or their ability to internalize Emab upon CD22 binding (NV Giltiay, unpublished data). Data from mouse and human studies have indicated that TLR7 can promote the production of auto-Abs $[13,28]$; because Blimp1 is required by $\mathrm{B}$ cells to mature into Abproducing cells, we propose that Emab-mediated inhibition of Blimp1 may reduce Ab/auto-Ab production. While the mechanisms for Emab-induced inhibition of B-cell differentiation need further elucidation, our data suggest that one therapeutic effect of Emab may be via inhibiting the expression of PRDM1 (Blimp1). In this respect, it is highly relevant that there is elevated 
expression of Blimp1 in SLE patients and this is correlated with increases in plasma cells, auto-Abs, and disease activity [83].

Interestingly, Emab also affected cell survival, although this effect was only evident within the (pre-GC/GC) $\mathrm{CD} 10^{+} \mathrm{CD} 27^{+/-}$cell population. A possible explanation for these data is that cells within this mixed cell population might be more sensitive to CD22-induced apoptosis. While apoptosis induction is not considered the primary mode of action of Emab, previous in-vitro data have demonstrated that crosslinking of CD22 by mAbs including Emab induces apoptosis in human lymphoma cells [84, 85]. Recently, Macauley et al. [43] demonstrated that changes in the glycosylation patterns due to altered enzyme activity in the GC leads to "unmasking" of CD22 binding site on GC B cells, relative to naïve and memory B cells. Such unmasking could very well alter the effects of CD22 binding by Emab. It should be noted that the effects of Emab on GC cell survival in culture were independent of BCR/TLR7 stimulation. These data, however, may be relevant to the clinical effects of Emab in patients with NHL, because GC B cells are considered a major source (i.e., cell of origin) for lymphoma cells $[46,86]$.

Despite initial promising data in phase II clinical studies $[52,53]$, results reported recently from a phase III clinical trial in SLE patients with moderate to severe disease showed that Emab failed to reach the primary clinical endpoint [87]. It has been suggested that a high placebo response and early rescue of nonresponders with increased doses of glucocorticoids might have confounded the data from the trial $[87,88]$. Although disappointing, these results reflect to a large extent the complexity and diversity of the pathology of SLE and suggest that perhaps some, but not all, SLE patients would benefit from Emab therapy. In our study, we have found that Emab affects the production of cytokines in response to BCR/TLR7 stimulation, by skewing $B$ cells to produce immunoregulatory cytokines such as IL-10. Thus, we can predict that targeting CD22 with Emab might be able to restore IL-10 production by $\mathrm{CD} 27^{-} \mathrm{CD} 24^{\mathrm{hi}} \mathrm{CD} 38^{\mathrm{hi}}$ transitional B cells in SLE patients. Transitional B cells are expanded in some SLE patients and our data showed that these cells express relatively high levels of CD22, suggesting that this cell population might be a good target for Emab therapy.

Our study identified $\mathrm{CD} 10^{-} \mathrm{CD} 27^{-} \mathrm{IgD}{ }^{-}$as another important cell population, whose responses to BCR/TLR7 stimulation were affected by Emab. We believe this cell population closely resembles the DN memory B cells found in the blood. We found a significant variation in the frequency of this B-cell population in tonsils, which we think might be reflective of environmental factors, such as recent viral exposure. An increased frequency of DN memory B cells has been described previously in
SLE patients $[4,5]$. Although there has been no direct evidence for their contribution to disease pathology, DN memory B cells have been linked to SLE autoimmunity $[4,5]$. For example, a significant portion of DN memory cells found in SLE patients produce VH4-34-encoded 9G4 Abs, known to be a source of SLE-associated autoreactivity [89]. Frequencies of DN memory B cells were found to be associated with higher disease activity, history of nephritis, and presence of auto-Abs $[4,5]$. The cellular origin of DN memory B cells remains somewhat elusive; because these cells express switched isotypes, yet at the same time show a reduced rate of somatic hypermutations compared to post-switched memory B cells, it has been proposed that they might be of extra-GC origin [5]. Recent studies have shown that a substantial fraction of Ab-secreting cell clones found during SLE flares contained auto-Abs without (or with very few) mutations, consistent with differentiation outside GCs [90].

Whether TLR-mediated activation of DN B cells might contribute to the generation of Ab-secreting clones has not been established. One study has shown that DN memory $\mathrm{B}$ cells are also highly responsive to stimulation through TLR9 by CpG [4]. Here, we reported that these cells are also highly responsive to stimulation through TLR7 by R848 or a combination of anti-IgM and TLR7. Importantly, we demonstrated a new role for CD22 in regulating the activation of these cells and their differentiation into $\mathrm{CD} 27^{\mathrm{hi}} \mathrm{CD} 38^{\mathrm{hi}} \mathrm{Blimp} 1^{+}$plasmablasts. In this study, we did not address in detail whether DN cells produce cytokines. In a limited set of experiments, we found that DN cells produced lower levels of IL-6 and IL-10 in response to TLR7 and or BCR/TLR7 stimulation, compared to naïve $\mathrm{B}$ cells; however, this needs to be investigated further. Recent reports describe an increase in DN memory B cells in RA patients and older people [91, 92]. Although the link between DN B cells and SLE disease activity seems well established, we have found a significant variation of DN memory B-cell frequencies in SLE patients, even those with active disease (NV Giltiay, unpublished data). In light of these findings, one can predict that patients with high frequencies of $\mathrm{DN}$ memory $\mathrm{B}$ cells might be better candidates for CD22 targeting by Emab.The fact that Emab blocks B cell differentiation in a distinct subset of memory B cells is also consistent with our studies in mice showing that CD22 is required for normal memory B cell formation [93].

Recent data suggest that Blimp1 levels positively correlate with the levels of pathogenic auto-Abs in SLE patients and can be used as a potential biomarker for monitoring disease activity [83]. Although results from the EMBODY1 and EMBODY2 trials showed no significant reduction of the total IgG levels and/or anti-DNA titers in Emab-treated patients [87], it would be of interest in the future to test whether decreases in Blimp1 levels 
and auto-Ab titers are associated with responses to Emab in vivo.

\section{Conclusions}

Together, our data show that binding of CD22 by Emab can both regulate cytokine expression and block Blimp1dependent B-cell differentiation in response to BCR/TLR7 stimulation. The effects of Emab depend on the stage of Bcell development or activation. A better understanding of the differential effects of Emab on different B-cell populations, including its effects on cell survival and cell activation, would provide important information on how best to use Emab in a clinical setting. We found that Emab inhibits the activation of $\mathrm{CD}^{2} 7^{-} \mathrm{IgD}^{-}(\mathrm{DN})$ cells which are highly responsive to stimulation via TLR7 and which are known to be expanded in some but not all SLE patients. The therapeutic effect of Emab in SLE might be via modulating the production of pro-inflammatory and anti-inflammatory cytokines by B cells, or by inhibiting the survival and/or differentiation of specific B-cell populations. Because Blimp1 is required by $\mathrm{B}$ cells to mature into Ab-producing cells, CD22-mediated inhibition of Blimp1 may also reduce auto- $\mathrm{Ab}$ production. Intriguingly, given the failure of Emab to demonstrate efficacy in a general SLE patient population, levels of Blimp1 expression could possibly be used as a biomarker to predict clinical responses to Emab in SLE and in patients with other autoimmune diseases.

\section{Additional files}

Additional file 1: Table S1. Presenting the primer sequences used for RT-PCR. (PDF $116 \mathrm{~kb}$ )

Additional file 2: Figure S1. Showing negative selection for $\mathrm{CD}_{10}^{-}$ CD27 ${ }^{-}$B-cell enrichment. (A) Schematic representation of the selection process, which involves depletion of $\mathrm{CD} 2^{+}$cells by rosetting, followed by depletion of $\mathrm{CD}^{+}, \mathrm{CD}^{+}, \mathrm{CD} 0^{+}$, and $\mathrm{CD} 27^{+}$cells using magnetic bead separation. (B) Representative flow data showing frequencies of $\mathrm{CD}_{2} \mathrm{O}^{+}$ ( $B$ cells) and frequencies of different B-cell populations after the enrichment. (PDF $138 \mathrm{~kb}$ )

Additional file 3: Figure S2. Showing that Emab does not affect the expression of BCR inducible genes and genes associated with TLR signaling. Tonsillar $\mathrm{CD} 10^{-} \mathrm{CD} 27^{-} \mathrm{B}$ cells were negatively selected using magnetic bead cell separation and then stimulated with R848 (TLR7 agonist) and/or anti-human $\mathrm{F}\left(\mathrm{ab} \mathrm{b}^{\prime}\right)_{2}$ lgM with or without Emab or a human IgG control. RNA was isolated 12 hours after stimulation and expression of different genes was quantified by RT-PCR. Graphs show combined data of three independent experiments, presented as mean \pm SD. (PDF $41 \mathrm{~kb}$ )

Additional file 4: Figure S3. Showing that IFN-a priming increases TLR7 expression and promotes IL-10 production, which is further enhanced in the presence of Emab. (A) Tonsillar CD10-CD27- B cells were stimulated with IFN-a (100 U/ml) for 3-12 hours. Increase of TLR7 levels presented as fold increase relative to unstimulated cells at 3 hours. (B) Cells were left untreated or IFN-a-primed for 6 hours, and then stimulated with $\mathrm{R} 848$ and/or $\mathrm{F}\left(\mathrm{ab} \mathrm{b}^{\prime}\right)_{2}$ anti-human IgM with or without Emab or a human IgG control. Graphs show the levels of IL-10 production after 3 days of cell culture. Data shown are representative of three independent experiments with similar results. (PDF $27 \mathrm{~kb}$ )
Additional file 5: Figure S4. Showing the sorting strategy for isolation of $\mathrm{CD}_{10^{-} \mathrm{CD} 27^{-} \mathrm{lgD}}^{-}$and $\mathrm{CD} 10^{-} \mathrm{CD} 27^{-} \mathrm{lgD}{ }^{+}$cells. Tonsillar $\mathrm{CD} 19^{+} \mathrm{B}$ cells were enriched by rosetting and stained with fluorescently labeled mAbs: anti-CD3, CD10, CD27, and IgD Abs. CD10-CD27 ${ }^{-}$cells were separated based on their lgD expression and sorted into $\mathrm{CD}_{10}^{-} \mathrm{CD}_{2}^{-} \mathrm{IgD}^{-}$or $\mathrm{CD}_{10}^{-}$ $\mathrm{CD}_{2} 7^{-} \mathrm{IgD}^{+}$populations using an Aria II high-speed sorter. Post-sort analysis shows the phenotype and purity of each of cell population. (PDF $116 \mathrm{~kb}$ )

\section{Abbreviations}

Ab: Antibody; Auto-Ab: Autoantibody; BCR: B-cell receptor; Blimp1: Blymphocyte-induced maturation protein 1; DN: Double negative; Emab: Epratuzumab; GC: Germinal center; IFN-a: Interferon alpha; IL: Interleukin; NHL: Non-Hodgkin's lymphoma; PCR: Polymerase chain reaction; pSS: Primary Sjögren's syndrome; RA: Rheumatoid arthritis; SLE: Systemic lupus erythematosus; TLR7: Toll-like receptor 7

\section{Acknowledgements}

The authors are grateful to Valley Medical Day Surgery Center for providing tonsils for this study. They also thank the University of Washington Department of Immunology Flow Cytometry Facility for support with cell sorting.

\section{Funding}

Funding for this study was provided by an unrestricted research grant from UCB Pharma and by NIH grant Al44257 (EAC).

\section{Availability of data and materials}

The datasets during and/or analyzed during the current study are available from the corresponding author on reasonable request.

\section{Authors' contributions}

NVG, GLS, and EAC designed the study. NVG and GLS performed the experiments and analyzed the data. NVG, GLS, AS, and EAC interpreted the results. NVG wrote the manuscript. EAC, GLS, and AS revised the manuscript and contributed to the discussion. All authors read and approved the final manuscript.

\section{Competing interests}

This study was supported by UCB Pharma. AS is an employee of UCB Pharma. EAC served as a consultant and received a research grant from UCB Pharma.

The remaining authors declare no competing interests.

\section{Consent for publication}

Not applicable.

Ethics approval and consent to participate

All studies involving human tissue were performed in accordance with an Institutional Review Board (IRB) approved protocol (University of Washington).

\section{Publisher's Note}

Springer Nature remains neutral with regard to jurisdictional claims in published maps and institutional affiliations.

\section{Author details}

${ }^{1}$ Division of Rheumatology, Department of Medicine, University of Washington, Seattle, WA 98109, USA. ²Department of Immunology, University of Washington, Seattle, WA 98109, USA. ${ }^{3}$ UCB Celltech, Slough, UK.

Received: 18 October 2016 Accepted: 24 March 2017

Published online: 15 May 2017

References

1. Anolik JH. B cell biology: implications for treatment of systemic lupus erythematosus. Lupus. 2013;22(4):342-9.

2. Dorner T, Giesecke C, Lipsky PE. Mechanisms of B cell autoimmunity in SLE. Arthritis Res Ther. 2011;13(5):243.

3. Tsokos GC. Systemic lupus erythematosus. N Engl J Med. 2011;365(22):2110-21.

4. Jacobi AM, Reiter K, Mackay M, Aranow C, Hiepe F, Radbruch A, Hansen A, Burmester GR, Diamond B, Lipsky PE, et al. Activated memory B cell subsets 
correlate with disease activity in systemic lupus erythematosus: delineation by expression of CD27, IgD, and CD95. Arthritis Rheum. 2008;58(6):1762-73.

5. Wei C, Anolik J, Cappione A, Zheng B, Pugh-Bernard A, Brooks J, Lee EH, Milner EC, Sanz I. A new population of cells lacking expression of CD27 represents a notable component of the B cell memory compartment in systemic lupus erythematosus. J Immunol. 2007;178(10):6624-33.

6. Dorner T, Jacobi AM, Lee J, Lipsky PE. Abnormalities of B cell subsets in patients with systemic lupus erythematosus. J Immunol Methods. 2011;363(2):187-97.

7. Jacobi AM, Odendahl M, Reiter K, Bruns A, Burmester GR, Radbruch A, Valet G, Lipsky PE, Dorner T. Correlation between circulating CD27 ${ }^{\text {high }}$ plasma cells and disease activity in patients with systemic lupus erythematosus. Arthritis Rheum. 2003;48(5):1332-42

8. Vincent FB, Morand EF, Schneider P, Mackay F. The BAFF/APRIL system in SLE pathogenesis. Nat Rev Rheumatol. 2014;10(6):365-73.

9. Giltiay NV, Chappell CP, Clark EA. B-cell selection and the development of autoantibodies. Arthritis Res Ther. 2012;14 Suppl 4:S1.

10. Fleischer SJ, Daridon C, Fleischer V, Lipsky PE, Dorner T. Enhanced Tyrosine phosphatase activity underlies dysregulated B Cell receptor signaling and promotes survival of human lupus B cells. Arthritis Rheumatol. 2016;68(5):1210-21.

11. Wu XN, Ye YX, Niu JW, Li Y, Li X, You X, Chen H, Zhao LD, Zeng XF, Zhang $F C$, et al. Defective PTEN regulation contributes to $B$ cell hyperresponsiveness in systemic lupus erythematosus. Sci Transl Med. 2014;6(246):246ra299.

12. Rifkin IR, Leadbetter EA, Busconi L, Viglianti G, Marshak-Rothstein A. Toll-like receptors, endogenous ligands, and systemic autoimmune disease. Immunol Rev. 2005;204:27-42.

13. Green NM, Marshak-Rothstein A. Toll-like receptor driven B cell activation in the induction of systemic autoimmunity. Semin Immunol. 2011;23(2):106-12

14. Celhar T, Magalhaes R, Fairhurst AM. TLR7 and TLR9 in SLE: when sensing self goes wrong. Immunol Res. 2012;53(1-3):58-77.

15. Santiago-Raber ML, Baudino L, Izui S. Emerging roles of TLR7 and TLR9 in murine SLE. J Autoimmun. 2009;33(3-4):231-8.

16. Lau CM, Broughton C, Tabor AS, Akira S, Flavell RA, Mamula MJ, Christensen SR, Shlomchik MJ, Viglianti GA, Rifkin IR, et al. RNA-associated autoantigens activate $B$ cells by combined B cell antigen receptor/Toll-like receptor 7 engagement. J Exp Med. 2005;202(9):1171-7.

17. Pisitkun $P$, Deane JA, Difilippantonio MJ, Tarasenko T, Satterthwaite AB, Bolland S. Autoreactive B cell responses to RNA-related antigens due to TLR7 gene duplication. Science. 2006;312(5780):1669-72.

18. Deane JA, Pisitkun P, Barrett RS, Feigenbaum L, Town T, Ward JM, Flavell RA, Bolland S. Control of toll-like receptor 7 expression is essential to restrict autoimmunity and dendritic cell proliferation. Immunity. 2007;27(5):801-10

19. Giltiay NV, Chappell CP, Sun X, Kolhatkar N, Teal TH, Wiedeman AE, Kim J, Tanaka L, Buechler MB, Hamerman JA, et al. Overexpression of TLR7 promotes cell-intrinsic expansion and autoantibody production by transitional T1 B cells. J Exp Med. 2013;210(12):2773-89.

20. Christensen SR, Shupe J, Nickerson K, Kashgarian M, Flavell RA, Shlomchik MJ. Toll-like receptor 7 and TLR9 dictate autoantibody specificity and have opposing inflammatory and regulatory roles in a murine model of lupus. Immunity. 2006;25(3):417-28.

21. Santiago-Raber ML, Dunand-Sauthier I, Wu T, Li QZ, Uematsu S, Akira S, Reith W, Mohan C, Kotzin BL, Izui S. Critical role of TLR7 in the acceleration of systemic lupus erythematosus in TLR9-deficient mice. J Autoimmun. 2010;34(4):339-48.

22. Hwang SH, Lee H, Yamamoto M, Jones LA, Dayalan J, Hopkins R, Zhou XJ, Yarovinsky F, Connolly JE, de Lafaille MA C, et al. B cell TLR7 expression drives anti-RNA autoantibody production and exacerbates disease in systemic lupus erythematosus-prone mice. J Immunol. 2012;189(12):5786-96.

23. Lee $Y H$, Choi SJ, Ji JD, Song GG. Association between toll-like receptor polymorphisms and systemic lupus erythematosus: a meta-analysis update. Lupus. 2016;25(6):593-601.

24. Kawasaki A, Furukawa H, Kondo Y, Ito S, Hayashi T, Kusaoi M, Matsumoto I, Tohma S, Takasaki Y, Hashimoto H, et al. TLR7 single-nucleotide polymorphisms in the $3^{\prime}$ untranslated region and intron 2 independently contribute to systemic lupus erythematosus in Japanese women: a casecontrol association study. Arthritis Res Ther. 2011;13(2):R41.

25. Shen N, Fu Q, Deng Y, Qian X, Zhao J, Kaufman KM, Wu YL, Yu CY, Tang Y, Chen JY, et al. Sex-specific association of X-linked Toll-like receptor 7 (TLR7) with male systemic lupus erythematosus. Proc Natl Acad Sci U S A. 2010;107(36):15838-43

26. Bekeredjian-Ding IB, Wagner M, Hornung V, Giese T, Schnurr M, Endres S, Hartmann G. Plasmacytoid dendritic cells control TLR7 sensitivity of naive B cells via type I IFN. J Immunol. 2005;174(7):4043-50.

27. Glaum MC, Narula S, Song D, Zheng Y, Anderson AL, Pletcher $\mathrm{CH}$, Levinson Al. Toll-like receptor 7 -induced naive human B-cell differentiation and immunoglobulin production. J Allergy Clin Immunol. 2009;123(1):224-30. e224.

28. Simchoni N, Cunningham-Rundles C. TLR7- and TLR9-responsive human B cells share phenotypic and genetic characteristics. J Immunol. 2015;194(7):3035-44.

29. Doody GM, Dempsey PW, Fearon DT. Activation of B lymphocytes: integrating signals from CD19, CD22 and Fc gamma Rllb1. Curr Opin Immunol. 1996;8(3):378-82.

30. Niiro H, Clark EA. Regulation of B-cell fate by antigen-receptor signals. Nat Rev Immunol. 2002;2(12):945-56.

31. Crocker PR, Paulson JC, Varki A. Siglecs and their roles in the immune system. Nat Rev Immunol. 2007;7(4):255-66.

32. Jellusova J, Nitschke L. Regulation of B cell functions by the sialic acidbinding receptors siglec-G and CD22. Front Immunol. 2011;2:96.

33. Nitschke L, Floyd H, Crocker PR. New functions for the sialic acid-binding adhesion molecule CD22, a member of the growing family of Siglecs. Scand J Immunol. 2001;53(3):227-34.

34. Nitschke L, Floyd H, Ferguson DJ, Crocker PR. Identification of CD22 ligands on bone marrow sinusoidal endothelium implicated in CD22-dependent homing of recirculating B cells. J Exp Med. 1999;189(9):1513-8.

35. Clark EA. CD22, a B cell-specific receptor, mediates adhesion and signal transduction. J Immunol. 1993;150(11):4715-8.

36. Walker JA, Smith KG. CD22: an inhibitory enigma. Immunology. 2008;123(3):314-25.

37. Dorner T, Shock A, Smith KG. CD22 and autoimmune disease. Int Rev Immunol. 2012;31(5):363-78.

38. Kawasaki N, Rademacher C, Paulson JC. CD22 regulates adaptive and innate immune responses of B cells. J Innate Immun. 2011;3(4):411-9.

39. Otipoby KL, Andersson KB, Draves KE, Klaus SJ, Farr AG, Kerner JD, Perlmutter RM, Law CL, Clark EA. CD22 regulates thymus-independent responses and the lifespan of B cells. Nature. 1996;384(6610):634-7.

40. Dorken B, Moldenhauer G, Pezzutto A, Schwartz R, Feller A, Kiesel S, Nadler LM. HD39 (B3), a B lineage-restricted antigen whose cell surface expression is limited to resting and activated human B lymphocytes. J Immunol. 1986;136(12):4470-9.

41. Daridon C, Blassfeld D, Reiter K, Mei HE, Giesecke C, Goldenberg DM, Hansen A, Hostmann A, Frolich D, Dorner T. Epratuzumab targeting of CD22 affects adhesion molecule expression and migration of B-cells in systemic lupus erythematosus. Arthritis Res Ther. 2010;12(6):R204.

42. Razi N, Varki A. Masking and unmasking of the sialic acid-binding lectin activity of CD22 (Siglec-2) on B lymphocytes. Proc Natl Acad Sci U S A. 1998;95(13):7469-74

43. Macauley MS, Kawasaki N, Peng W, Wang SH, He Y, Arlian BM, McBride R, Kannagi R, Khoo KH, Paulson JC. Unmasking of CD22 co-receptor on germinal center B-cells occurs by alternative mechanisms in mouse and man. J Biol Chem. 2015;290(50):30066-77.

44. Carnahan J, Wang P, Kendall R, Chen C, Hu S, Boone T, Juan T, Talvenheimo J, Montestruque S, Sun J, et al. Epratuzumab, a humanized monoclonal antibody targeting CD22: characterization of in vitro properties. Clin Cancer Res. 2003;9(10 Pt 2):3982S-90S.

45. Wei C, Jenks S, Sanz I. Polychromatic flow cytometry in evaluating rheumatic disease patients. Arthritis Res Ther. 2015:17:46.

46. Leonard JP, Coleman M, Ketas JC, Chadburn A, Ely S, Furman RR, Wegener WA, Hansen HJ, Ziccardi H, Eschenberg M, et al. Phase I/II trial of epratuzumab (humanized anti-CD22 antibody) in indolent non-Hodgkin's lymphoma. J Clin Oncol. 2003;21(16):3051-9.

47. Carnahan J, Stein R, Qu Z, Hess K, Cesano A, Hansen HJ, Goldenberg DM. Epratuzumab, a CD22-targeting recombinant humanized antibody with a different mode of action from rituximab. Mol Immunol. 2007; 44(6):1331-41.

48. Lumb S, Fleischer SJ, Wiedemann A, Daridon C, Maloney A, Shock A, Dorner T. Engagement of CD22 on B cells with the monoclonal antibody epratuzumab stimulates the phosphorylation of upstream inhibitory signals of the B cell receptor. J Cell Commun Signal. 2016;10(2):143-51. 
49. Sieger N, Fleischer SJ, Mei HE, Reiter K, Shock A, Burmester GR, Daridon C, Dorner T. CD22 ligation inhibits downstream B cell receptor signaling and $\mathrm{Ca}(2+)$ flux upon activation. Arthritis Rheum. 2013;65(3):770-9.

50. Dorner T, Goldenberg DM. Targeting CD22 as a strategy for treating systemic autoimmune diseases. Ther Clin Risk Manag. 2007;3(5):953-9.

51. Steinfeld SD, Tant L, Burmester GR, Teoh NK, Wegener WA, Goldenberg DM, Pradier O. Epratuzumab (humanised anti-CD22 antibody) in primary Sjogren's syndrome: an open-label phase I/II study. Arthritis Res Ther. 2006;8(4):R129.

52. Dorner T, Kaufmann J, Wegener WA, Teoh N, Goldenberg DM, Burmester GR. Initial clinical trial of epratuzumab (humanized anti-CD22 antibody) for immunotherapy of systemic lupus erythematosus. Arthritis Res Ther. 2006; 8(3):R74.

53. Wallace DJ, Kalunian K, Petri MA, Strand V, Houssiau FA, Pike M, Kilgallen B, Bongardt S, Barry A, Kelley L, et al. Efficacy and safety of epratuzumab in patients with moderate/severe active systemic lupus erythematosus: results from EMBLEM, a phase Ilb, randomised, double-blind, placebo-controlled, multicentre study. Ann Rheum Dis. 2014;73(1):183-90.

54. Jacobi AM, Goldenberg DM, Hiepe F, Radbruch A, Burmester GR, Dorner T. Differential effects of epratuzumab on peripheral blood B cells of patients with systemic lupus erythematosus versus normal controls. Ann Rheum Dis. 2008;67(4):450-7.

55. Rossi EA, Goldenberg DM, Michel R, Rossi DL, Wallace DJ, Chang CH. Trogocytosis of multiple B-cell surface markers by CD22 targeting with epratuzumab. Blood. 2013;122(17):3020-9.

56. Fleischer V, Sieber J, Fleischer SJ, Shock A, Heine G, Daridon C, Dorner T. Epratuzumab inhibits the production of the proinflammatory cytokines IL-6 and TNF-alpha, but not the regulatory cytokine IL-10, by B cells from healthy donors and SLE patients. Arthritis Res Ther. 2015;17:185.

57. Dorner T, Shock A, Goldenberg DM, Lipsky PE. The mechanistic impact of CD22 engagement with epratuzumab on B cell function: Implications for the treatment of systemic lupus erythematosus. Autoimmun Rev. 2015;14(12):1079-86

58. Saxon A, Feldhaus J, Robins RA. Single step separation of human T and B cells using AET treated srbc rosettes. J Immunol Methods. 1976;12(3-4):285-8.

59. Pezzutto A, Rabinovitch PS, Dorken B, Moldenhauer G, Clark EA. Role of the CD22 human B cell antigen in B cell triggering by anti-immunoglobulin. J Immunol. 1988;140(6):1791-5.

60. Sanz I, Wei C, Lee FE, Anolik J. Phenotypic and functional heterogeneity of human memory B cells. Semin Immunol. 2008;20(1):67-82.

61. Kjeldsen MK, Perez-Andres M, Schmitz A, Johansen P, Boegsted M, Nyegaard M, Gaihede M, Bukh A, Johnsen HE, Orfao A, et al. Multiparametric flow cytometry for identification and fluorescence activated cell sorting of five distinct B-cell subpopulations in normal tonsil tissue. Am J Clin Pathol. 2011;136(6):960-9.

62. Nutt SL, Hodgkin PD, Tarlinton DM, Corcoran LM. The generation of antibody-secreting plasma cells. Nat Rev Immunol. 2015;15(3):160-71.

63. Green NM, Moody KS, Debatis M, Marshak-Rothstein A. Activation of autoreactive B cells by endogenous TLR7 and TLR3 RNA ligands. J Biol Chem. 2012;287(47):39789-99.

64. Clark EA, Shu G. Activation of human B cell proliferation through surface Bp35 (CD20) polypeptides or immunoglobulin receptors. J Immunol. 1987;138(3):720-5.

65. Yoshizaki K, Nakagawa T, Fukunaga K, Tseng LT, Yamamura Y, Kishimoto T. Isolation and characterization of $B$ cell differentiation factor (BCDF) secreted from a human B lymphoblastoid cell line. J Immunol. 1984;132(6):2948-54.

66. Kishimoto T, Taga T, Yamasaki K, Matsuda T, Tang B, Muraguchi A, Horii Y, Suematsu S, Hirata $Y$, Yawata $H$, et al. Normal and abnormal regulation of human B cell differentiation by a new cytokine, BSF2/IL-6. Adv Exp Med Biol. 1989;254:135-43.

67. Dienz O, Eaton SM, Bond JP, Neveu W, Moquin D, Noubade R, Briso EM, Charland C, Leonard WJ, Ciliberto G, et al. The induction of antibody production by IL-6 is indirectly mediated by IL-21 produced by CD4+ T cells. J Exp Med. 2009;206(1):69-78.

68. Eto D, Lao C, DiToro D, Barnett B, Escobar TC, Kageyama R, Yusuf I, Crotty S. $\mathrm{IL}-21$ and IL-6 are critical for different aspects of B cell immunity and redundantly induce optimal follicular helper CD4 T cell (Tfh) differentiation. PLoS One. 2011;6(3):e17739.

69. Jain S, Park G, Sproule TJ, Christianson GJ, Leeth CM, Wang H, Roopenian DC, Morse 3rd HC. Interleukin 6 accelerates mortality by promoting the progression of the systemic lupus erythematosus-like disease of BXSB.Yaa mice. PLoS One. 2016;11(4):e0153059.
70. Bryant VL, Ma CS, Avery DT, Li Y, Good KL, Corcoran LM, de Waal MR, Tangye SG. Cytokine-mediated regulation of human B cell differentiation into Ig-secreting cells: predominant role of IL-21 produced by CXCR5+ T follicular helper cells. J Immunol. 2007;179(12):8180-90.

71. Linker-Israeli M, Deans RJ, Wallace DJ, Prehn J, Ozeri-Chen T, Klinenberg JR. Elevated levels of endogenous IL-6 in systemic lupus erythematosus. A putative role in pathogenesis. J Immunol. 1991;147(1):117-23.

72. Rosser EC, Mauri C. Regulatory B cells: origin, phenotype, and function. Immunity. 2015;42(4):607-12.

73. Flores-Borja F, Bosma A, Ng D, Reddy V, Ehrenstein MR, Isenberg DA, Mauri C. CD19 + CD24hiCD38hi B cells maintain regulatory T cells while limiting TH1 and TH17 differentiation. Sci Transl Med. 2013;5(173):173ra123.

74. Blair PA, Norena LY, Flores-Borja F, Rawlings DJ, Isenberg DA, Ehrenstein MR, Mauri C. CD19(+)CD24(hi)CD38(hi) B cells exhibit regulatory capacity in healthy individuals but are functionally impaired in systemic Lupus Erythematosus patients. Immunity. 2010;32(1):129-40.

75. Bouaziz JD, Calbo S, Maho-Vaillant M, Saussine A, Bagot M, Bensussan A Musette P. IL-10 produced by activated human B cells regulates CD4(+) T-cell activation in vitro. Eur J Immunol. 2010;40(10):2686-91.

76. Sim JH, Kim HR, Chang SH, Kim IJ, Lipsky PE, Lee J. Autoregulatory function of interleukin-10-producing pre-naive B cells is defective in systemic lupus erythematosus. Arthritis Res Ther. 2015;17:190.

77. Liu BS, Cao Y, Huizinga TW, Hafler DA, Toes RE. TLR-mediated STAT3 and ERK activation controls IL-10 secretion by human B cells. Eur J Immunol. 2014:44(7):2121-9.

78. Law CL, Sidorenko SP, Chandran KA, Zhao Z, Shen SH, Fischer EH, Clark EA. CD22 associates with protein tyrosine phosphatase 1C, Syk, and phospholipase C-gamma(1) upon B cell activation. J Exp Med. 1996;183(2):547-60.

79. Poe JC, Fujimoto M, Jansen PJ, Miller AS, Tedder TF. CD22 forms a quaternary complex with SHIP, Grb2, and Shc. A pathway for regulation of B lymphocyte antigen receptor-induced calcium flux. J Biol Chem. 2000;275(23):17420-7.

80. Otipoby KL, Draves KE, Clark EA. CD22 regulates B cell receptor-mediated signals via two domains that independently recruit Grb2 and SHP-1. J Biol Chem. 2001;276(47):44315-22.

81. Tuscano JM, Riva A, Toscano SN, Tedder TF, Kehrl JH. CD22 cross-linking generates B-cell antigen receptor-independent signals that activate the JNK/SAPK signaling cascade. Blood. 1999;94(4):1382-92.

82. Maloney AHD, Rapecki S, Fossati G, Lumb S, Rosen D, Putta S, Wale N, Spellmeyer D, Cesano A, Hawtin R and Shock A. Epratuzumab induces broad inhibition of B cell receptor proximal signaling but has opposing effects on distal signaling in B cell subsets: a profile of effects on functional immune signaling by single cell network profiling. Arthritis Rheum. 2014;66(Suppl 10):S1255-6

83. Luo J, Niu X, Liu H, Zhang M, Chen M, Deng S. Up-regulation of transcription factor Blimp1 in systemic lupus erythematosus. Mol Immunol. 2013;56(4):574-82.

84. Chaouchi N, Vazquez A, Galanaud P, Leprince C. B cell antigen receptormediated apoptosis. Importance of accessory molecules CD19 and CD22, and of surface IgM cross-linking. J Immunol. 1995;154(7):3096-104.

85. Chang $\mathrm{CH}$, Wang Y, Gupta P, Goldenberg DM. Extensive crosslinking of CD22 by epratuzumab triggers BCR signaling and caspase-dependent apoptosis in human lymphoma cells. MAbs. 2015;7(1):199-211.

86. Basso K, Dalla-Favera R. Germinal centres and B cell lymphomagenesis. Nat Rev Immunol. 2015;15(3):172-84.

87. Clowse ME, Wallace DJ, Furie RA, Petri MA, Pike MC, Leszczynski P, Neuwelt CM, Hobbs K, Keiserman M, Duca L, et al. Efficacy and safety of epratuzumab in moderately to severely active systemic lupus erythematosus: results from two phase III randomized, double-blind, placebo-controlled trials. Arthritis Rheumatol. 2017;69(2):362-75.

88. Mahieu MA, Strand V, Simon LS, Lipsky PE, Ramsey-Goldman R. A critical review of clinical trials in systemic lupus erythematosus. Lupus. 2016:25(10):1122-40.

89. Isenberg D, Spellerberg M, Williams W, Griffiths M, Stevenson F. Identification of the $9 \mathrm{G} 4$ idiotope in systemic lupus erythematosus. Br J Rheumatol. 1993;32(10):876-82.

90. Tipton CM, Fucile CF, Darce J, Chida A, Ichikawa T, Gregoretti I, Schieferl S, Hom J, Jenks S, Feldman RJ, et al. Diversity, cellular origin and autoreactivity of antibody-secreting cell population expansions in acute systemic lupus erythematosus. Nat Immunol. 2015;16(7):755-65. 
91. Mahmood Z, Muhammad K, Schmalzing M, Roll P, Dorner T, Tony HP. CD27-lgD- memory B cells are modulated by in vivo interleukin-6 receptor (IL-6R) blockade in rheumatoid arthritis. Arthritis Res Ther. 2015;17:61.

92. Colonna-Romano G, Bulati M, Aquino A, Pellicano M, Vitello S, Lio D, Candore G, Caruso C. A double-negative (IgD-CD27-) B cell population is increased in the peripheral blood of elderly people. Mech Ageing Dev 2009;130(10):681-90

93. Craig P. Chappell, Kevin E. Draves, Edward A. Clark. CD22 is required for formation of memory B cell precursors within germinal centers. PLOS ONE. 2017;12(3):e0174661

Submit your next manuscript to BioMed Central and we will help you at every step:

- We accept pre-submission inquiries

- Our selector tool helps you to find the most relevant journal

- We provide round the clock customer support

- Convenient online submission

- Thorough peer review

- Inclusion in PubMed and all major indexing services

- Maximum visibility for your research

Submit your manuscript at www.biomedcentral.com/submit
Biomed Central 